CREATING A POSITIVE MEGA-EVENT LEGACY: EXPLORING THE IMPACT OF THE PAN AMERICAN GAMES ON THE WEST DON LANDS COMMUNITY, TORONTO

by

Alexandra Nicole Goldstein, BA, Ryerson University, 2011

\author{
A Major Research Paper \\ presented to Ryerson University \\ in partial fulfillment of the requirements for the degree of \\ Master of Planning \\ in \\ Urban Development
}

Toronto, Ontario, Canada, 2011

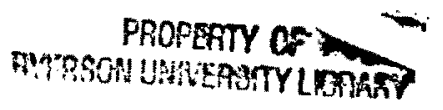

(C) Alexandra Nicole Goldstein 


\section{Author's Declaration}

I herby declare that I am the sole author of this major research paper.

I authorize Ryerson University to lend this paper to other institutions or individuals for the purpose of scholarly research.

I further authorize Ryerson University to reproduce this paper by photocopying or by other means, in total or in part, at the request of other institutions or individuals for the purpose of scholarly research. 


\title{
CREATING A POSITIVE MEGA-EVENT LEGACY: EXPLORING THE IMPACT OF THE PAN AMERICAN GAMES ON THE WEST DON LANDS COMMUNITY, TORONTO
}

\author{
(C) Alexandra Nicole Goldstein, 2011 \\ Master of Planning \\ in \\ Urban Development \\ Ryerson University
}

\begin{abstract}
In November 2009, the Pan American Sports Organization (PASO) announced that Toronto won the bid to host the 2015 Pan and Parapan American Games. The Toronto bid included many ambitious policies and challenging development projects. One of the most notable development projects is the construction of the Athletes' Village on the West Don Lands (WDL), a former industrial area that Waterfront Toronto has been working to revitalize. The construction of the Village is supposed to compliment the existing plan for the WDL revitalization, as outlined in the Precinct Plan, which aims to develop the site into a mixed-use community. The intent of this Masters Research Paper is to explore whether using the WDL as a temporary site for the Village will leave a positive post-game legacy, where the goals originally set for the site are actualized. Lessons learned from three previous Olympic village conversions will be used to develop four factors that indicate whether a successful post-game village conversion will occur on the West Don Lands.
\end{abstract}

Key Words:

Key words: West Don Lands; Toronto; Precinct Plan; Pan American Games; Athletes' Village; Mega-Events; Legacy. 


\section{ACKNOWLEDGEMENTS}

I am thankful to my supervisor, Dr. Zhixi Cecilia Zhuang, who provided me with encouragement, guidance and support through the entire process of writing my Masters Research Paper. Her patience, optimism and advice was hugely important to me.

I would also like to offer my regards to the professors, peers, family and friends who offered assistance to me during the completion of my project. I truly appreciated your insight.

Alexandra N. Goldstein 


\section{Table of Contents}

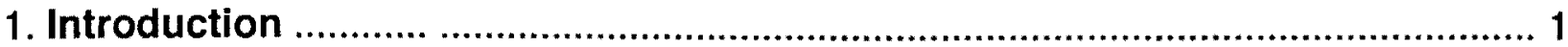

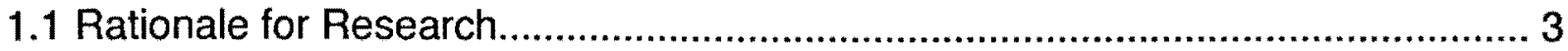

1.2 Review of Literature: What is a Mega-Event and Why Host Them? ................... 6

1.2.1 Positive legacies arising from mega-events ............................................... 7

1.2.2 Negative legacies arising from mega-events .......................................... 10

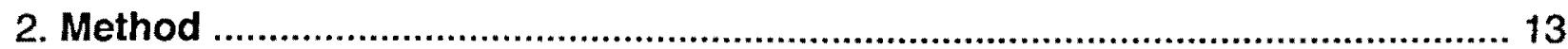

3. Toronto's Next Mega-Event: Setting the Context ........................................... 15

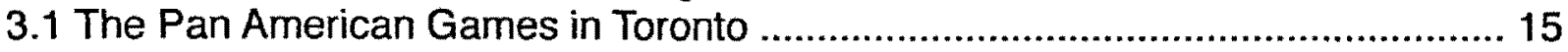

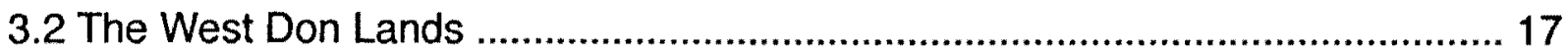

3.3 The Precinct Plan \& Visions for the West Don Lands ....................................... 20

3.3.1 Precinct plan vision 1: develop a mixed-use neighborhood ....................... 21

3.3.2 Precinct plan vision 2: integration, connectivity and accessibility ................ 22

3.3.3 Precinct plan vision 3: sustainable development and design ..................... 22

3.3.4 Precinct plan vision 4: recognize the history of the site ............................. 24

3.4 The Pan American Village Plan and Visions ................................................... 25

4. Indicators for Success \& Lessons Learned from Earlier Village Conversions . 29

4.1 Create a Post- Game Plan ............................................................................ 29

4.2 Ensure the Village Site is Integrated and Accessible to the Rest of the City ...... 34

4.3 Design the Site for Compact, Mixed-Uses ...................................................... 37

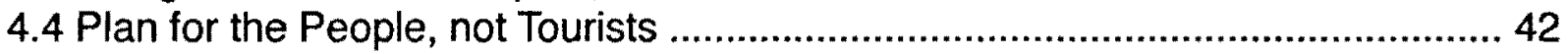

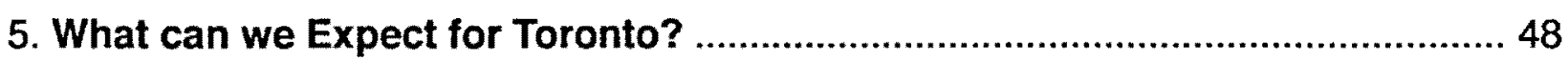

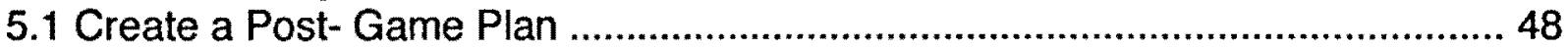

5.2 Ensure the Village Site is Integrated and Accessible to the Rest of the City ...... 49

5.3 Design the Site for Compact, Mixed-Uses ..................................................... 54

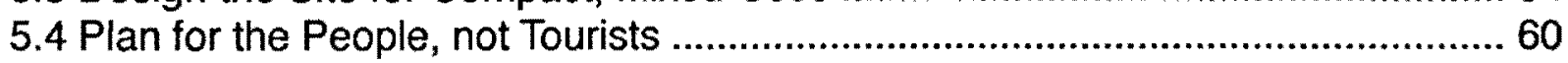

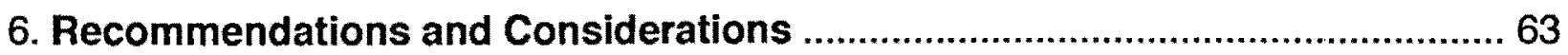

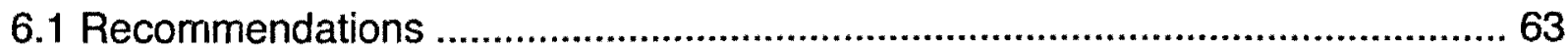

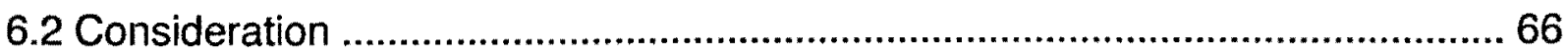

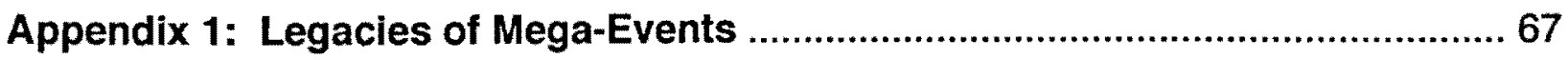

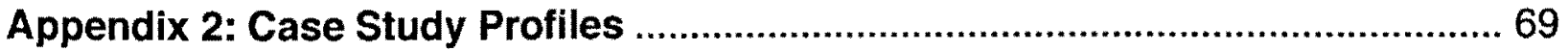

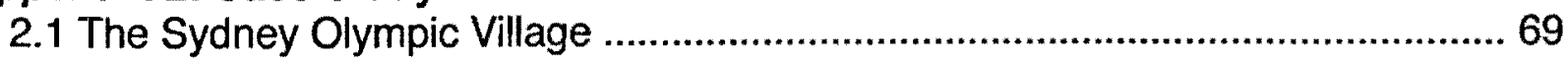

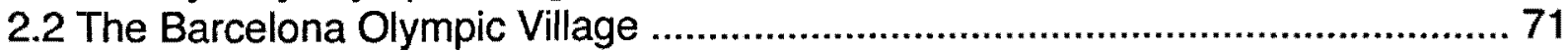

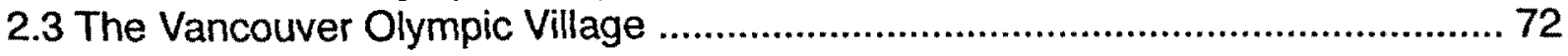

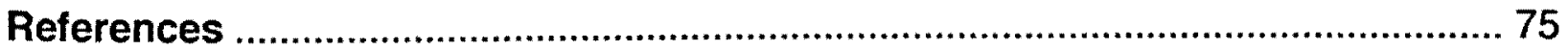




\section{List of Figures}

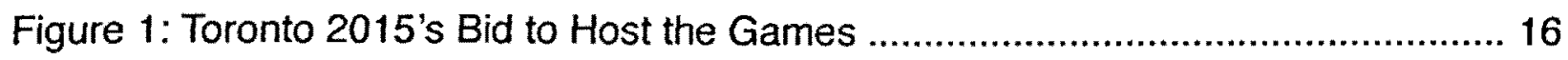

Figure 2: Satellite Image of West Don Lands .......................................................... 19

Figure 3: Context Map for West Don Lands …........................................................ 19

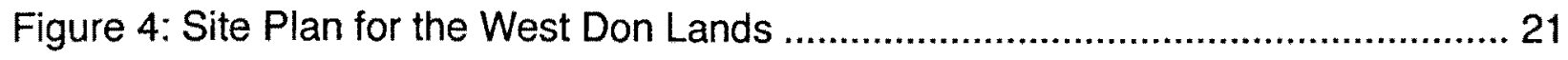

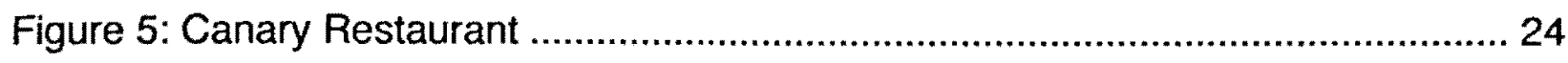

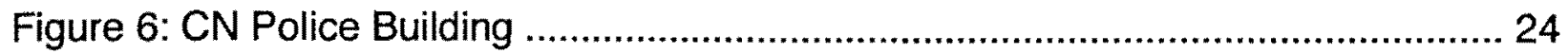

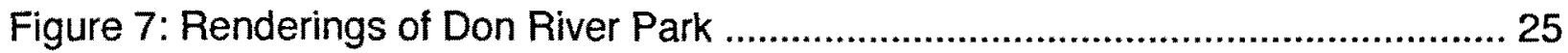

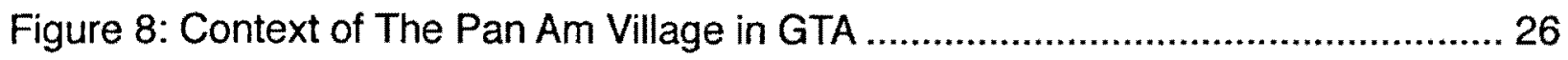

Figure 9: The Athletes' Village Site Plan ........................................................... 27

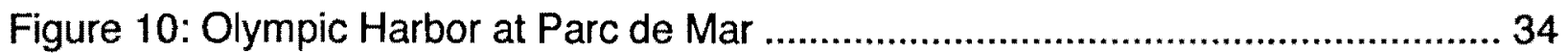

Figure 11: Cycling and Pedestrian Paths Through the Olympic Park ........................ 35

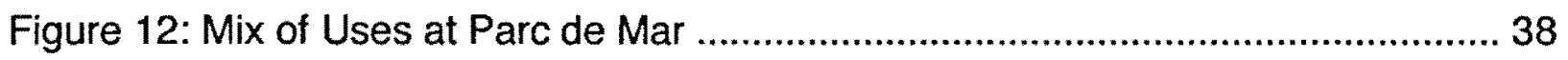

Figure 13: Single Detached Neighborhood in Newington .......................................... 39

Figure 14: Rendering of Future Haslams Precinct ....................................................... 40

Figure 15: Rendering of SEFC Site ....................................................................... 41

Figure 16: The Monumental Scale of Sydney Olympic Park .................................... 46

Figure 17: Building Heights in Storeys .................................................................. 50

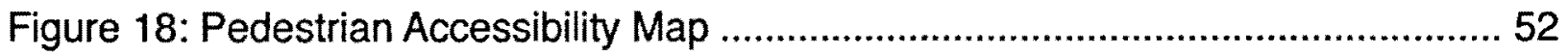

Figure 19: Transit Accessibility Map ......................................................................... 53

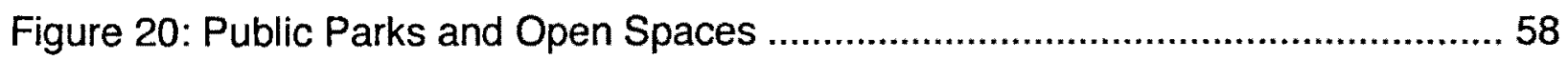

Figure 21: Built Heritage Features to be Incorporated into the Site ........................... 59

Figure 22: Four Neighborhood Districts ..................................................................6 66 


\section{Introduction}

In early November 2009, the Pan American Sports Organization (PASO) announced that Toronto won the bid to host the 2015 Pan and Parapan American Games. The Games will bring together 8,500 athletes and coaches from all the nations in the Americas in the spirit of athletic competition (Mays, 2009). The Toronto bid includes many ambitious policies (such as the first-ever Diversity Policy for the competition) and challenging development projects. The most notable development project is the construction of the Athletes' Village on the West Don Lands (WDL), a former industrial area that Waterfront Toronto has been working to revitalize. The construction of the Village is supposed to compliment the WDL revitalization project, which intends to develop the site into a mixed-use community. Plans for the redevelopment began several years ago and involved extensive community and public consultation, culminating in the creation of the West Don Lands Precinct Plan (Waterfront Toronto Revitalization Corporation, 2004). It is expected that following the Games, the Village will transition into the mixed-use community that Waterfront Toronto originally envisioned for the site.

Those who support hosting the Games in Toronto are excited not only by the idea that the City will have an opportunity to showcase itself to the rest of the world, attract tourism and leverage economic investment, but also by the fact that the revitalization process for the WDL will be fast-tracked (MacFarlane, 2010). Winning the bid, according to John Campbell, the president and CEO of Waterfront Toronto, accelerates the development (Starr, 2010). In turn the speed in which affordable housing, servicing, 
transportation routes and vitality will be brought to the underserved area will increase. Conversely, some critics worry that speeding up the revitalization process will lead to a rush for completion and ultimately ignore some of the key visions and goals outlined in the Precinct Plan (Terefenco, 2009; Mays, 2009). The design guidelines for the sight, including the height, size of footprint and building envelop, have been developed over several years and were meant to be implemented over at least a decade, depending on market conditions and housing absorption rates (Mays, 2009).

Due to the time constraints requiring the Village to be completed by 2015 , it is feared that "design quality could be sacrificed for expediency" as pressure may cause developers to cut corners and eliminate refinements that should be part of the waterfront community (Mays, 2009). However, zoning is in place and site preparation, including soil and groundwater remediation and the construction of a flood control berm, has been underway for three years. As a result, the construction of the Village will not be starting from scratch. Campbell argues that "there's time to make the right decisions and to do things properly" (Starr, 2010). Further, according to John Campbell, "we're not changing the design (of the West Don Lands)...we have a plan that the community has embraced, that council has approved, and that's what is going to get built" (Starr, 2010). Campbell affirms that "rather than [building] a village for athletes and [figuring] out what to do with it afterward, we're building a village for the City and we're going to use it temporarily for the athletes" (Starr, 2010). He then goes on to state that Waterfront Toronto will be working "to avoid what happens on a lot of waterfronts, where you get 
narrow demographic enclaves of certain age groups and certain income groups" (Starr, 2010).

It is the intent of my Masters Research Paper (MRP) to explore this further and gain an understanding of how the temporary Athletes' Village on the WDL could shape the future community that is to be built there. Specifically, I will be trying to answer how the construction of the Village will impact the actualization of the visions and goals outlined in the Precinct Plan and subsequently, the WDL. I will be doing this by looking at indicators, derived from past precedents and case studies, of what enables athlete villages to be successfully converted into a new use following a mega-event. I will then link those indicators to the Precinct and Village Plans, thereby allowing me to draw conclusions of what Toronto can expect of the WDL following the Games. The specific case studies that will be examined are the:

- Barcelona Olympic Games (1992);

- Sydney Olympic Games (2000); and

- Vancouver Olympic Games (2010).

\subsection{Rationale for Research}

There are many reasons why it is important to understand the impact of the temporary Athletes' Village on the WDL. It is well recognized that the Pan Am Games will act as a catalyst for the redevelopment and renewal of the WDL. The anticipated timeline for the completion of the mixed-use neighborhood was estimated to be between 12 and 20 years, depending on a variety of factors, and is now going to take place in just over five. 
As mentioned earlier, this condensed schedule has many people skeptical and fearful that the original visions for the site, as outlined in the Precinct Plan, will be ignored, and that the quality of construction and design will be compromised because of the Games, resulting in a no-frills, mediocre neighborhood (Terefenko, 2009). Torontonians, Canadians and the rest of the world are anxiously waiting to see what will become of the fragile site following its temporary use as an athletes' village, hoping that the shortened build-out time does not sacrifice the quality of the community. Understanding indicators of what allows for a successful post-game conversion may be helpful for avoiding such problems.

It is also important to pursue this research because the WDL will be one of the first sites revitalized as part of Waterfront Toronto's ambitious waterfront redevelopment mandate. As such, it will act as an archetype; the nature of its design, sustainability, accessibility and affordability will set the tone and act as a guiding standard for all other waterfront projects (Mays, 2009). According to John Mays (2008), the presence of the Village may act as "a possible hitch in Waterfront Toronto's efforts to bring urban vitality to the water..." If the ambitious visions and goals outlined in the Precinct Plan are overlooked, such as the provision of affordable housing, it will set a low precedent for the rest of the waterfront. Understanding how to avoid a poor transition from a temporary athletes' village to a neighborhood will enable planners to adjust their methods and plans for the Athletes' Village. 
Further, the way that the West Don Lands neighborhood unfolds following the Games may also set the tone for how residents of the Greater Golden Horseshoe perceive the positive and negative aspects of hosting mega-events. Toronto is the only major city in Canada to have never hosted a significant sporting event, despite its numerous efforts. Two recent bids to host the Olympics were lost, the latest being an attempt to host the 2016 summer Games (Hume, 2008). Those Games were awarded to Rio de Janeiro, which hosted the 2007 Pan American Games (Hume, 2008). It is believed that like in Rio, if Toronto successfully hosts the Pan Am Games, it may act as a catalyst to winning the Olympic bid. The reasons why cities want to host the Olympic Games are numerous, and expanded upon in the next section (Chalkey \& Essex, 1999). If the Athletes' Village does not interfere with the actualization of the West Don Lands neighborhood, as many people fear, then the Games will leave a positive legacy that could generate support for subsequent mega-events.

Finally, what happens on the WDL following the Pan American Games will also set the tone for how Torontonians judge the public consultation process. Over the past 10 years, the public and relevant stakeholders have been asked to reflect on the strengths, weaknesses and opportunities that are embedded within the WDL, and what they envision the site to look like upon build-out. Their thoughts and concerns are addressed by the Precinct Plan. If the construction of the Athletes' Village on the site changes the anticipated character and appearance of the West Don Lands community, the public will lose faith in the public and stakeholder engagement process. Using the four indicators could help to prevent that from occurring. 


\subsection{Review of Literature: What is a Mega-Event and Why Host Them?}

The term "mega-event" is cften used to describe high profile events that attract national and international attention to host cities. They occur over a well defined period of time, bringing with them opportunities for commerce, investment, competition, celebration and world cooperation (Chalkey \& Essex, 1999; Bret, 1984). They showcase the symbolic capital of a host by displaying the physical attributes, taste and eminence that sets the city apart from others (Chalkey \& Essex, 1998). Although sporting events have become the most studied mega-event over the last three decades, with the largest being the Olympics, fairs, festivals and exhibitions can also be classified as mega-events (Chalkey \& Essex, 1999; Gratton, Shibli \& Coleman, 2005).

The potential legacies that result from such events has made hosting them attractive. A legacy can be defined as an events' potential to generate a broad set of positive or negative outcomes for a host city following its closure (McCartney, 2010). Due to the rising cost of hosting mega-events, especially those based around athletic competition, support for holding them can really only be gained if the event is promoted to result in a positive post-game legacy. What is complex about many mega-event legacies, both positive and negative, is that they often do not surface until many years after the event (International Olympic Committee, 2010). For a detailed summary of positive and negative legacies, refer to Appendix 1. 


\subsubsection{Positive legacies arising from mega-events.}

One of the most sited yet controversial legacies of hosting a mega-event is the economic spin-offs that may arise (Potsiou, 2005; Bret, 1984; Gold \& Gold, 2008). In the short term, the events can act as a stimulus to the construction industry, resulting in the creation of numerous jobs (Gold \& Gold, 2008; McCartney, 2010; Bret, 1984). This was the case in Salt Lake City, where the preparation for the 2002 Olympics generated an estimated 35,000 jobs per year between 1996 and 2002 (International Olympic Committee, 2010). Beyond the creation of jobs, hosting a mega-event can result in economic investments from national and international investors. For example, in the decade following the 1996 Olympic Games in Atlanta, 280 additional international businesses opened their offices there (International Olympic Committee, 2010). Finally, mega-events can stimulate tourism in the short and long term by attracting people who want to observe the event and by promoting the host city in a positive light (Potsiou, 2005; Andranovich, Burbank, \& Heying, 2001; Gold \& Gold, 2008). By consciously using a mega-event as a publicity and marketing tool, host cities are able to communicate with the world a certain image of itself, making it an interesting destination to visit during and following an event (Gold \& Gold, 2008).

One of the most difficult yet positive economic legacies to achieve is the generation of a profit. There have been very few mega sporting events that have been able to do this, the most known being the Atlanta and LA summer Olympic Games (Andranovich et al., 2001). LA was able to generate a profit of over $\$ 2$ million in 1984 by using existing facilities and infrastructure rather than building new ones, and by encouraging private 
investment (Andranovich et al., 2001). Similarly, Atlanta avoided a public deficit by encouraging investors to buy advertising rights to the Games, leading to more ticket sales (Kapadia, 2008). According to Andrew Young, the mayor of Atlanta at the time, "the Olympics were a business venture, not an anti-poverty campaign" (Kapadia, 2008).

Another benefit of hosting a mega-event is the fact that they can lead to civic betterment. They can be used as a mechanism for beautifying a city, leading to park and street clean ups, tree plantings, improved street lighting and better identification of monuments (Potsiou, 2005). Further, mega-events can act as a vehicle for facilitating social interactions (Bret, 1984). Following the 1992 Barcelona summer Olympic Games, the City's waterfront was restored, leading to the opening of a beachfront area with restaurants, bars and retail businesses, enhancing opportunities for social interaction (Swaddle, 2010). The resulting facilities from an event, such as sport venues and convention centers can also enable social interactions and may result in recreational enjoyment and athletic excellence (Bret, 1984). Finally, hosting a mega-event can lead to national and local pride in ones city (McCartney, 2010), thus leading to a sense of unity and strengthened identity (Chalkey \& Essex, 1999). This is especially true when an event draws on the traditions, values and interests of the local population (Bret, 1984)

Environmental protection and enhancement projects are another positive legacy that can arise from hosting a mega-event (Potsiou, 2005; Chalkey \& Essex, 1999). The most common form that this takes is the creation, cleanup or expansion of parks and open 
spaces (Chalkey \& Essex, 1999). For the Atlanta Olympic Games, Centennial Park was created by greening 10 blocks of a blighted neighborhood, urban parks were rejuvenated throughout the downtown core and nearly 2000 trees planted (International Olympic Committee, 2010). For the 2000 Sydney Olympic Games, 160 hectares of degraded land was restored, leading to the creation of the largest urban park in Australia. Within it, there are conserved and enhanced wetlands and forests and native flora and fauna (International Olympic Committee, 2010). Finally, Barcelona used the Olympics to clean up more than 100 acres of industrial seafront lands (International Olympic Committee, 2010). More recently, legacies of environmental sustainability are becoming the norm, with the Sydney Olympic Village setting the precedent. The Sydney Village is well known for its environmentally sustainable structures, such as its solar powered residential suburb and district water system (Lochead, 2006).

Ultimately, the most sought after legacy of hosting a mega-event is their potential to lead to urban regeneration, renewal and improvement. This is because they often target a range of physical, social, environmental and economic problems in a well coordinated way, such as building new facilities, expanding existing infrastructure, and redeveloping blighted areas (Coaffe, 2008). Without the mega-events, most projects would not be financially or politically feasible (Bret, 1984). According to David Wellechinsky, the Vice President of the International Society of Olympic Historians, there is often an "argument over whether [a mega-event] is the improper use of money... My belief is it is a way to accelerate infrastructure investment that benefits the host city for a long 
time" (Gunderson-Hunt, 2009). The potential of urban benefit is one of the reasons why there are more bids to host events today than in the past (Chalkey \& Essex, 1999).

\subsubsection{Negative legacies arising from mega-events.}

Although there are numerous benefits to hosting mega-events, such high profile projects can carry great risks (Andranovich et al., 2001). One of the greatest risk is that mega-events can provide an outlet for civic opposition, international boycotts and terrorist activities (Chalkey \& Essex, 1999). In terms of terrorism, the gathering of large groups from countries around the world provides an opportunity for inflicting fear. This is best illustrated with the 1972 Munich Olympics where a total of eleven Israeli athletes were murdered (Gold \& Gold, 2008).

As with almost all mega-events, citizens of the host city question the "unjustified" spending on facilities and infrastructure necessary to host such events, often resulting in boycotts, protests and political disputes (Chalkey \& Essex 1998). Prior to the 1968 Mexico City Olympic Games, thousands of activists protested against hosting,. They felt that the money would be better spent on improving the extreme housing and poverty issues facing the City. The protests culminated in police intervention and 250 student deaths (Chalkey \& Essex, 1999). A less extreme example of public resistance to hosting mega-events is illustrated with the Salt Lake City Olympics, where protesters were concerned about the provision of affordable housing following the games and the protection of the civil liberties of the homeless population (Lenskyj, 2008). 
Another negative outcome associated with hosting mega-events is that they often interfere with residents and place the needs of tourists ahead of the host population's (Andranovich et al., 2001). Further, the desire of a host city to create a spectacle can overshadow the needs of marginalized people, such as the elderly, minority groups, low income earners and the homeless (Chalkey \& Essex, 1999), exacerbating social inequalities (Chalkey \& Essex, 1998). According to Andranovich et al. (2001), "providing festivals when people need bread is a dubious use of public resources." This was seen in Atlanta, where the unnecessary construction of Centennial Park created ill will among local residents who bore the brunt of the housing loss and dislocation (Andranovich et al., 2001). A similar situation was seen in Barcelona where a total of 624 families were displaced and relocated (Lenskyj, 2008). They were forced to leave their homes to allow for the construction of sporting facilities and ring roads (Kapadia, 2008). Further unhappiness among the public occurs following mega-events when property values begin to increase due to gentrification, displacing people who can no longer afford to live in their neighborhoods (Kapadina, 2008).

Along with the negative social legacies associated with mega-events, there are also numerous economic issues. The most wide-spread concern is that these events can leave the host city in financial distress, thereby impacting the provision of education, health and social services (McCartney, 2010). Financial shortages may be caused by inflated construction costs, especially when workers are paid overtime to complete facilities expediently (Gratton et al., 2005), poor budgeting, and overspending (Gunderson-Hunt, 2009). The most notorious case of financial loss from hosting a mega 
sporting event can be seen with the Montreal Olympic Games in 1976 where their population was too small to support the substantial costs of hosting (Millet, 2007).

Further, a large proportion of funding shortages are linked to the high cost of maintaining facilities following the end of a mega-event (Chalkey \& Essex, 1999; Gold \& Gold, 2008). Often, especially with sporting events, highly specialized facilities are required to host, such as veledromes, but are too specialized to be used by the general public (Gratton et al., 2005). Without a high volume of users, maintaining specialized facilities is extremely expensive (Swaddle, 2010). Further, the facilities are too large to be used in a way that could generate a profit. In 2000 , the Olympic Stadium in Montreal was demolished because it was unable to secure a permanent tenant who could afford its maintenance bill (Swaddle, 2010). Now, many facilities, especially Olympic facilities, are designed with a post-event use in mind.

It is clear that the benefits and risks associated with the legacies of hosting a megaevent can be variable and unpredictable (Chalkey \& Essex, 1998). For that reason, it is extremely important for event planners and governments to use forethought prior to the event (Gunderson-Hunt, 2009). This will enable them to plan for positive legacies while preventing negative legacies from arising. This is a valuable lesson that the Pan American Games should control for. 


\section{Method}

The information presented in my MRP is based on secondary research and qualitative data derived from government and international agencies and private sources. Qualitative research often depends upon the interpretation of social data (Neuman, 2006). The use of secondary data involves the "analysis of previously collected survey or other data that was originally gathered by others" (Neuman, 2006). In contrast to primary research, secondary research focuses on analyzing as opposed to collecting data. Use of secondary data allowed me to focus largely on interpreting existing information and drawing conclusions about the expected legacy of the Pan Am Games in Toronto. Using secondary data also allows the researcher to explore issues from an angle that has not previously been examined (Neuman, 2006). Finally, it allows for comparisons across groups, regions and times which was important due to my thorough examination of a variety of case studies and previous precedents (Neuman, 2006).

My research was done in several phases. I began by first reviewing past mega-events and their post-game legacies, specifically looking at athlete villages. I consulted government reports, scholarly journal articles and official Olympic Committee documents, archives and websites, as well as material by various NGOs, activist groups and community members. I did this broad review to get a general sense of the role such events play within a host city and what legacies, good and bad, result from hosting them. I also did it to gain an understanding of mega-events to avoid making erroneous assumptions and false interpretations in my analysis (Neuman, 2006). 
Following my review on mega-events I began a close examination of the West Don Lands Precinct Plan, the Pan American Village Plan, as well as relevant newspaper and journal articles related to the Pan American Games in Toronto. After completing a review of the literature, I was able to narrow down appropriate case studies that would be helpful for my analysis of what circumstances indicate that a successful post-game village conversion will happen. As mentioned earlier, the Games that I chose to look at were the Barcelona (1992), Sydney (2000) and Vancouver (2010) Olympic Games. These case studies were chosen for a variety of reasons. They all offer both lessons of success and failure that can be applied to the Toronto context. Further, their villages were built on valuable underutilized lands, near the city centre, as will be the case with the 2015 Pan Am Games. A profile of each Game's village can be seen in Appendix 2.

Following an in-depth review of the three Games, I was able to extrapolate four major indicators that enable successful post-game conversions. Those indicators, which will be expanded upon later in this paper are: the existence of a thorough post-game plan prior to the construction of an athletes' village, the degree of accessibility of the site to the general public, the ability of the site to accommodate a mix of uses, and whether the site meets the needs of the local population. Using those indicators and some findings from my review on mega-event legacies, I was able to hypothesize whether the original vision for the WDL would be actualized following the Pan American Games. 


\section{Toronto's Next Mega-Event: Setting the Context}

\subsection{The Pan American Games in Toronto}

The Pan American Games are a sporting event held every four years, bringing together athletes and coaches from 42 countries across the Americas and the Caribbean. In October of 2008 the City submitted a bid to host the Games; the bid was drafted and designed by the Toronto based architecture firm regionalArchitects, under the leadership of John van Nostrand and Drew Sinclair (Mays, 2009). On November 6, 2009, it was announced that Toronto had won the bid to host the 2015 Games, beating out Bogata, Columbia and Lima, Peru. It is estimated that the Games will bring 250,000 tourists to the City, create 17,000 construction jobs and generate approximately $\$ 2$ billion in economic spinoffs, thus acting as a major stimulus for the City (Hanes, 2008). The Games will not take place solely in Toronto; sporting events and their required infrastructure will be spread out across 12 municipalities throughout the Greater Golden Horseshoe (Lu, 2008). Toronto specifically will hold soccer, basketball and baseball events, and the opening and closing ceremonies. The Athletes' Village will also be located in Toronto.

The Game's potential to leave behind a legacy of high quality sport facilities, expedient travel networks and positive place promotion on an international scale has been used leverage support for hosting. Further, the Games are being promoted based on the promise of spurring spending on necessary infrastructure improvements and moving some projects towards completion. For example, according to John Campbell, the Games will act as a critical push for the revitalization efforts of the waterfont by 
transforming a "meandering 15-year route to new waterfront housing into a frantic sprint to conjure up dining halls and dormitories in a third of that time" (Mehler-Paperny, 2009).

With only six years to plan and construct the necessary facilities and infrastructure, the City and Toronto 2015 (the Game's organizing committee) has been working extremely hard, under the leadership of lan Troop, the CEO of Toronto 2015 , to get the ball rolling.

The price-tag for hosting the Games, which includes construction, infrastructure and operation costs, was estimated to be approximately $\$ 1.4$ billion. This price

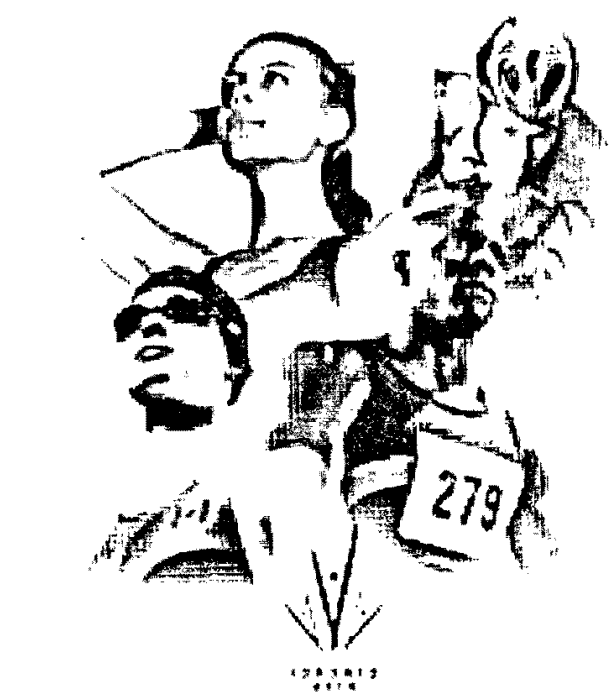

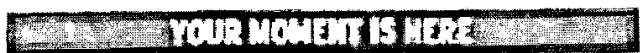

Figure 1: Toronto 2015's Bid to Host the Games. Source: (Toronto 2015, 2008) however, has been subject to increases due to inflation and unforeseen issues. The funding will come from all three levels of government. The construction cost of the Village is estimated to be approximately $\$ 1$ billion, which is not included in the overall Games budget, although all of its operating costs during the Games will be (Lewington, 2009).

The Athletes' Village will consist of both temporary and permanent structures which will help its conversion into a mixed-use, sustainable community following the Games. The temporary structures include the dining hall and kitchen, the welcome centre, training facilities and other components that are specifically linked to the Games (Mays, 2009; 
Lu, 2, 2009). The permanent structures will include mid-rise apartment blocks and townhouses that will provide approximately 2,100 residential units for the 8,500 athletes, coaches and officials (Starr, 2010; Paperny-Mehler, 2010). Following the Games, those units will be converted into livable dwellings for the local population (Mays, 2009). Both types of structures should conform to the Waterfront Design Guidelines which includes height, footprint and building envelope specifications (Mays, 2009).

Although some people see the opportunity to host the Games as a positive achievement for Toronto, others feel that it will be detrimental. Groups and coalitions such as No Games Toronto and Bread not Circuses, oppose the Games. They fear that they will divert resources and attention away from issues of homelessness, high tuition fees, and social housing, and leave behind a legacy of debt (Hanes, 2009). One of the greatest concerns is that cost overruns from the Games will impact the provision of affordable housing originally promised for the West Don Lands neighborhood, citing the Vancouver Olympic Games as an example. According to Helen Lenskyj, a professor at the University of Toronto in the Sociology Department, "every time there is a promise of affordable housing in Olympic cities, when it has materialized, it is only a very small portion" (Lu, 2009).

\subsection{The West Don Lands}

The West Don Lands are a 32 hectare ( 80 acres) parcel of land that runs from

Parliament Street in the west to the Don River, and from King Street in the north to the rail corridor (Waterfront Toronto, 2010). Centrally located in the context of Toronto, the 
WDL are within walking distance of the financial district, the waterfront and the Don River. Further, the site is bordered by a number of diverse communities. The St. Lawrence neighborhood is located to the west, the historical Corktown neighborhood is located to the north and the renewed Gooderham \& Worts Distillery District is located on the western fringe of the WDL.

With a history dating back to the 1700s, the WDL have always been a unique space within the City. Under the direction of Lieutenant Governor Simcoe, the provincially owned land was designated as a Park Reserve in 1793, preventing noxious developments from occurring on or near it (West Don Lands Committee, 2000). However, as the City faced growth pressures the land was relinquished in 1813, enabling industrial facilities to locate there (West Don Lands Committee, 2000). After more than 100 years, those industries began to relocate outside of the City, leaving behind both contaminated soil and groundwater (Waterfront Toronto Revitalization Corporation, 2005). Lacking the resources to clean up the site, the land remained vacant for many years. It was not until the late 1980 s when attention began to focus on the WDL once again.

In 1988, the City and province, under the Liberal leadership of David Peterson, attempted to renew the site by expropriating it for reuse as an affordable residential neighborhood (West Don Lands Committee, 2000; Waterfront Toronto Revitalization Corporation, 2005). That project however, was cancelled in 1993 after more than $\$ 300$ million was invested in it (Waterfront Toronto Revitalization Corporation, 2005). A 
collapse in the real estate market, high interest rates and the prohibitive cost of flood protection and soil remediation meant the project would cost a minimum of $\$ 1$ billion, a price many taxpayers were unwilling to pay (Waterfront Toronto Revitalization Corporation, 2005). The project was further doomed by protesters who opposed building a low income neighborhood on previously contaminated land (West Don Lands Committee, 2000).

In 1996, three years after the project failed, the province tried to sell the land to private developers to recover its lost investments. Despite some interest, by 1999 it still remained unsold (West Don

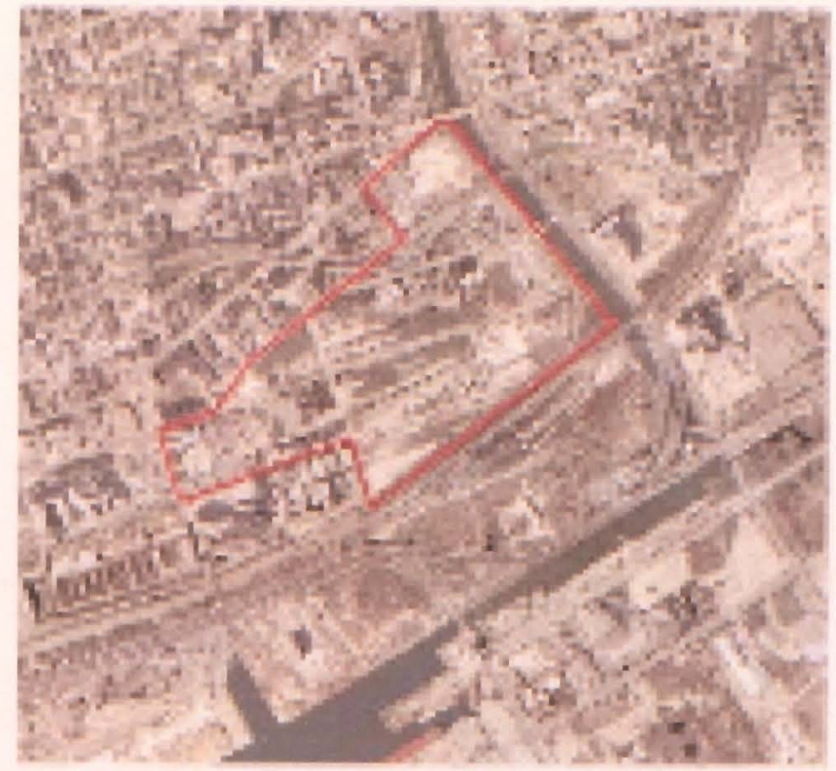

Figure 2: Satellite Image of West Don Lands Source: (WTRC, 2004)

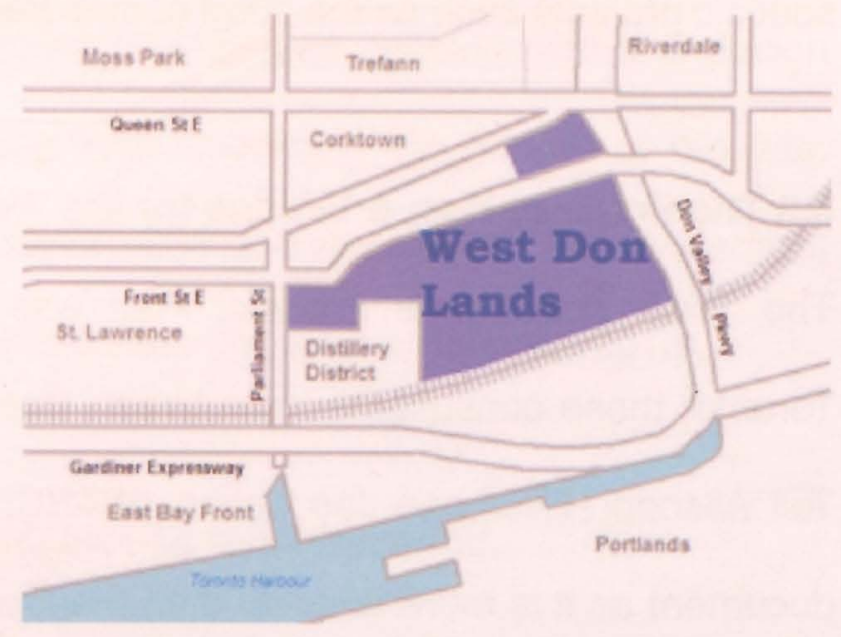

Figure 3: Context Map for West Don Lands Source: (WTRC, 2004)

Lands Committee, 2000). It was then that the provincial government decided to retain ownership of the site and devise a new plan to renew and revive the WDL. In 2001, the federal, provincial and local government created Waterfront Toronto (formerly Toronto Waterfront Revitalization Corporation). Its mandate is to oversee and lead the renewal of Toronto's central waterfront, in which the WDL were named a priority area (Waterfront Toronto Revitalization Corporation, 2005). In 2005 Waterfront Toronto became the lead 
developer of the site (Waterfront Toronto Revitalization Corporation, 2005). Below it, three other major organizations are also involved in the revitalization project: the Ontario Realty Corporation, the Toronto and Region Conservation Authority, and the Toronto Community Housing Corporation.

Before any work began on the site, several community and stakeholder meetings were held to gage the public's opinions and preferences. The findings from the consultation process, along with Waterfront Toronto's visions for the WDL were incorporated into a detailed Precinct Plan and Block Plans. Once the Precinct Plan was approved in 2005, specific projects such as the flood control berm, began.

\subsection{The Precinct Plan \& Visions for the West Don Lands}

The West Don Lands Precinct Plan was developed by consultants for Waterfront Toronto; those consultants were Urban Design Associates, LEA, Earth Tech, GHK, du Toit Allsopp Hillier and Joe Lobko (WTRC, 2004). The Precinct Plan is an important document as it is more detailed than the Central Waterfront Secondary Plan. It sets out visions, goals, development principles and guidelines specific to the revitalization of the WDL neighborhood. Further, it investigates the strengths, weaknesses and opportunities presented by the site. It analyzes those features, including street patterns, street types, municipal services and community facilities, and the investments required to improve and accommodate them (WTRC, 2004). The Precinct Plan also delineates guidelines for the built form of the site, such as land use and massing guides and the character that its five main neighborhoods will take, which is further detailed in the Block Plans. It 
provides a timeline and strategy for achieving the complete construction of the WDL (WTRC, 2004). The Plan received the Award of Excellence in the Vision and Master Plans category in 2005 in the City of Toronto's Architecture and Urban Design Awards (Waterfront Toronto, 2010).

There are a series of key ideas and themes that emerge several times throughout the Precinct Plan. Due to their repetition, it is apparent that those themes form the main principles and visions for the site. I have consolidated the key themes into four primary visions. They are: the development of a mixed-use neighborhood; making the site integrated, connected and accessible; employing sustainable development and design throughout the WDL; and finally, recognizing and respecting the history of the site. These are expanded below. Interestingly, those visions complement what Waterfront Toronto envisioned for the entire City's waterfront area (Waterfront Toronto, 2010).

\subsubsection{Precinct plan vision 1: develop a mixed-use neighborhood.}

The first overarching vision for the WDL is to have the site become a mixed-use residential neighborhood with an emphasis on urban living. Within the neighborhood, a variety of uses residential, retail, commercial and parkland - will be presented, thus attracting a diverse range of visitors,

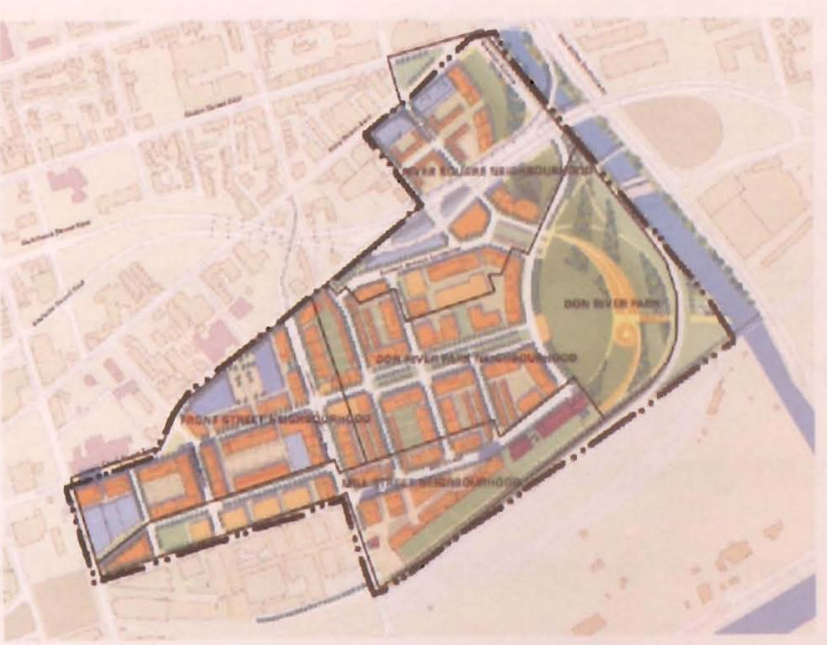

Figure 4: Site plan for the West Don Lands Source: (WTRC, 2004) 
workers and dwellers (WTRC, 2004). Housing will be provided at a range of prices, tenure types and styles, thus appealing to a wide demographic. The site will be made attractive to retail and commercial establishments and subsequent workers through accessibility improvements. This will help ensure the site is vibrant throughout the day. Parks, open spaces and leisure activities will also be developed on the site, attracting visitors from all over the City and region.

\subsubsection{Precinct plan vision 2: integration, connectivity and accessibility.}

Despite the fact that the WDL are located close to downtown Toronto and are embedded in the Don River Valley Corridor, the site is often perceived to be isolated from the rest of the City. This can be explained by the fact that the area is poorly served by public transportation and has deteriorating roads, and because the presence of physical barriers to the site, such as the railway yards and the Don River (WTRC, 2004). Further, the existence of unique developments surrounding the WDL, such as the St. Lawrence and Corktown neighborhoods, means the site is often overlooked (WTRC, 2004). The second vision of the Precinct Plan aims to improve access to the site and its internal connections, and integrate it with the rest of the City.

\subsubsection{Precinct plan vision 3: sustainable development and design.}

The third vision is to have the WDL embrace sustainable development and design and smart growth principles. Waterfront Toronto is deeply committed to making Toronto's waterfront a national and global model of social, economic and environmental sustainability (WTRC, 2004). A socially sustainable community is one that is diverse, 
offering accommodations and support to a wide range of people and activities. The Precinct Plan for the West Don Lands aims to achieve social sustainability by creating a truly mixed-use community (WTRC, 2004). An economically sustainable community is one that is economically active and has a range of employment opportunities through the provision of retail and commercial activities (WTRC, 2004). Finally, an environmentally sustainable community is one where the environmental impacts of construction and occupation are accounted for and mitigated as much as possible in the development of a site (WTRC, 2004).

To achieve environmental sustainability, numerous regulations regarding land use, transportation, building design, energy use, air quality, materials waste and management, and natural resources will be implemented to ensure environmentally sound development occurs on the WDL. In all cases, Waterfront Toronto will require that each new building, prior to being constructed, demonstrate how it meets environmental goals (WTRC, 2004). Ultimately, Waterfront Toronto hopes that the WDL redevelopment achieves LEED Gold standard certification and becomes a candidate for LEED ND neighborhood design (WTRC, 2004). The LEED ND program goes beyond acknowledging energy-efficient buildings and looks towards community-scale characteristics, including density, walkability, affordability and community involvement (Toronto 2015, 2008). 


\subsubsection{Precinct plan vision 4: recognize the history of the site.}

Finally, given its unique history and context within the City, the Precinct Plan has made specific efforts to respect and pay homage to the character and historical features of the WDL. Some of the defining built features that add to the rugged charm of the WDL include red brick buildings, elongated chimneys, steel bridges and heavy concrete infrastructure (WTRC, 2004). To pay homage to these features, the Precinct Plan envisions that the historical street patterns will be preserved. Further, it makes sure that the roads retain their red brick gutters, that grey concrete sidewalk bands will exaggerate the narrow streets, and an industrial motif is present (WTRC, 2004). To emphasize the industrial theme, tree pit covers will be made of industrial steel checker plates, among other things (WTRC, 2004). The preservation of historical buildings will also provide a key link to the area's past. The Canary Restaurant and the former CN Police building, both located at the intersection of Cherry and

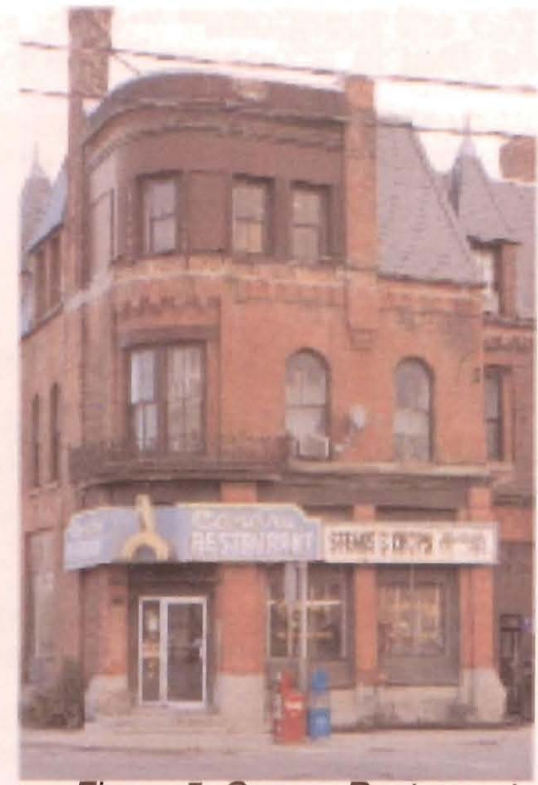

Figure 5: Canary Restaurant Source: (WTRC, 2004)

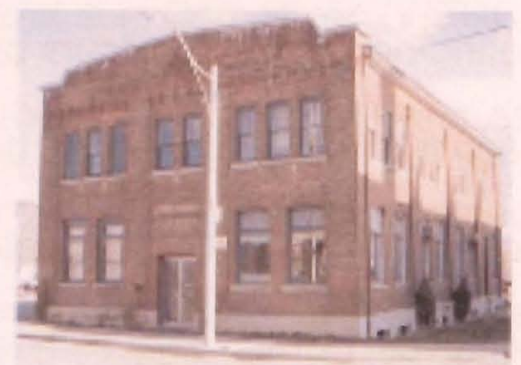

Figure 6: CN Police Building Source: (WTRC, 2004)

Front Street, will be incorporated into the redevelopment of the WDL, along with the original Dominion Foundry and its adjacent building and the Don River Train Station (WTRC, 2004). 
The natural history of the site has also influenced the Precinct Plan. The largest and most influential natural feature affecting the WDL is the Don River (WTRC, 2004). From the street patterns to the pedestrian passageways, the flowing movement and beauty of the River has inspired much of the design for the redevelopment of the site. For example, Don River Park, which is the central focus of the neighborhood, was designed specifically to bring attention to the Don River and to open it up to the City (WTRC, 2004). The Don River Park will also pay homage to the fact that prior to being an important industrial site, the WDL were considered a vibrant park space.
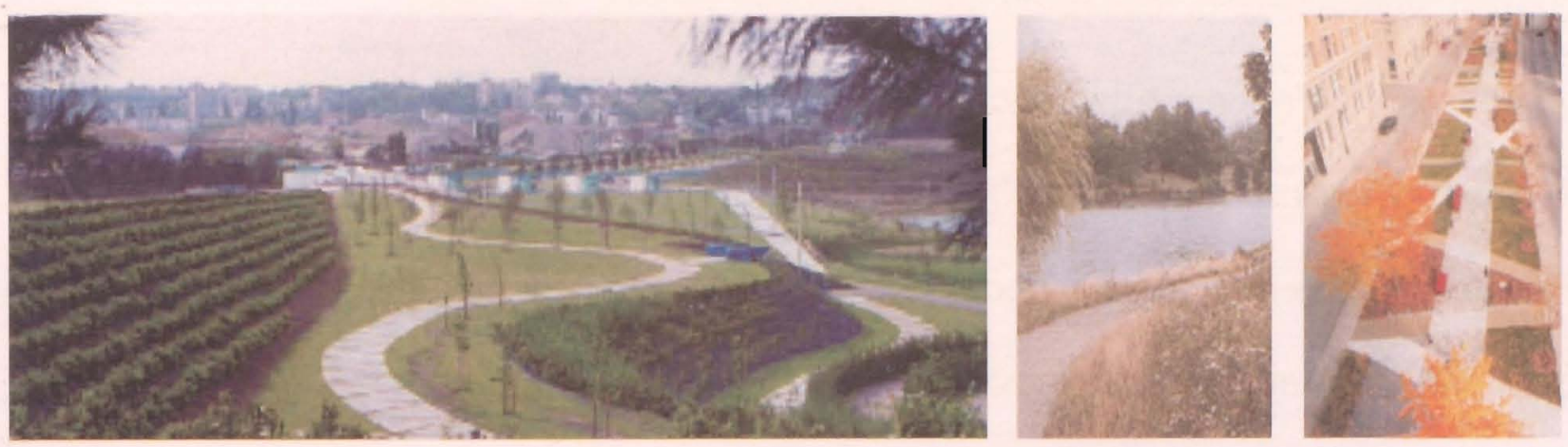

Figure 7: Renderings of Don River Park Source: (WTRC, 2004)

\subsection{The Pan American Village Plan and Visions}

The Pan American Village Plan (2008), which was developed by Toronto 2015, recognizes the existence of the Precinct Plan as well as the more detailed block plans for each district within the site. It does this by stating that the WDL "has been the subject of extensive visioning and planning work, the result of which is an award-winning plan for waterfront redevelopment..." These plans form the foundation on which all the planning for the Village has been based (Waterfront Toronto, 2010). The Precinct Plan and its policies are important for the construction of the Village, as the Village Plan resembles a site plan rather than a well developed planning document. 
The Village Plan outlines the visions and development guidelines for the Athletes" Village that is to be developed on an 80 -acre site within the WDL. The rationale for choosing to locate the Village in the WDL is based on the fact that the site is uniquely positioned. It is just east of downtown Toronto, within a 25 minute commute to most of the Games venues, and less than 25 minutes from Pearson International Airport (Toronto 2015, 2008). Further, the site was chosen because

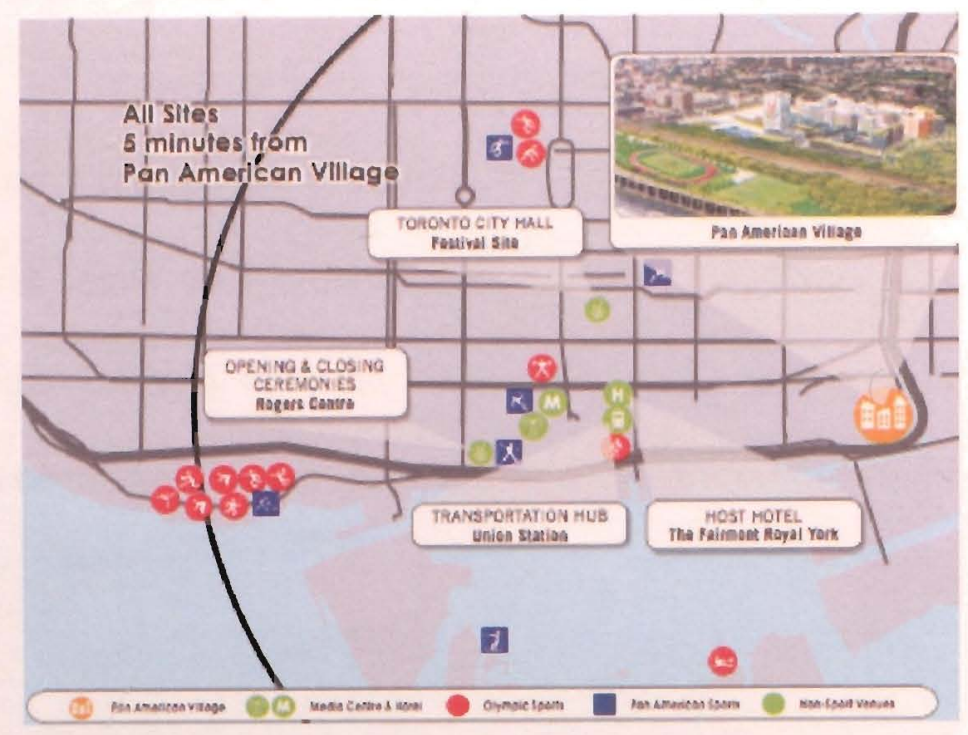

Figure 8: Context of The Pan Am Village in GTA Source: (Toronto 2015, 2008)

of its state of readiness; Waterfront Toronto had already begun preparing the site for the construction of a mixed-use community. The construction of supporting infrastructure and planning approvals had already begun, enhancing the likelihood that the Village will be complete on time (Toronto 2015, 2008).

The Village facilities will meet the requirements set out in the International Olympic Committee's Technical Manual on Olympic Village, and thus will strive to provide a safe and comfortable living and leisure environment for the athletes and officials participating in the Games (Waterfront Toronto, 2010). The Village Plan divides the WDL into several components and 'zones', each with different uses including the Welcome Centre, the 
International Zone, the Residential Zone, the Operations Zone and the Transport Mall (Toronto 2015, 2008).

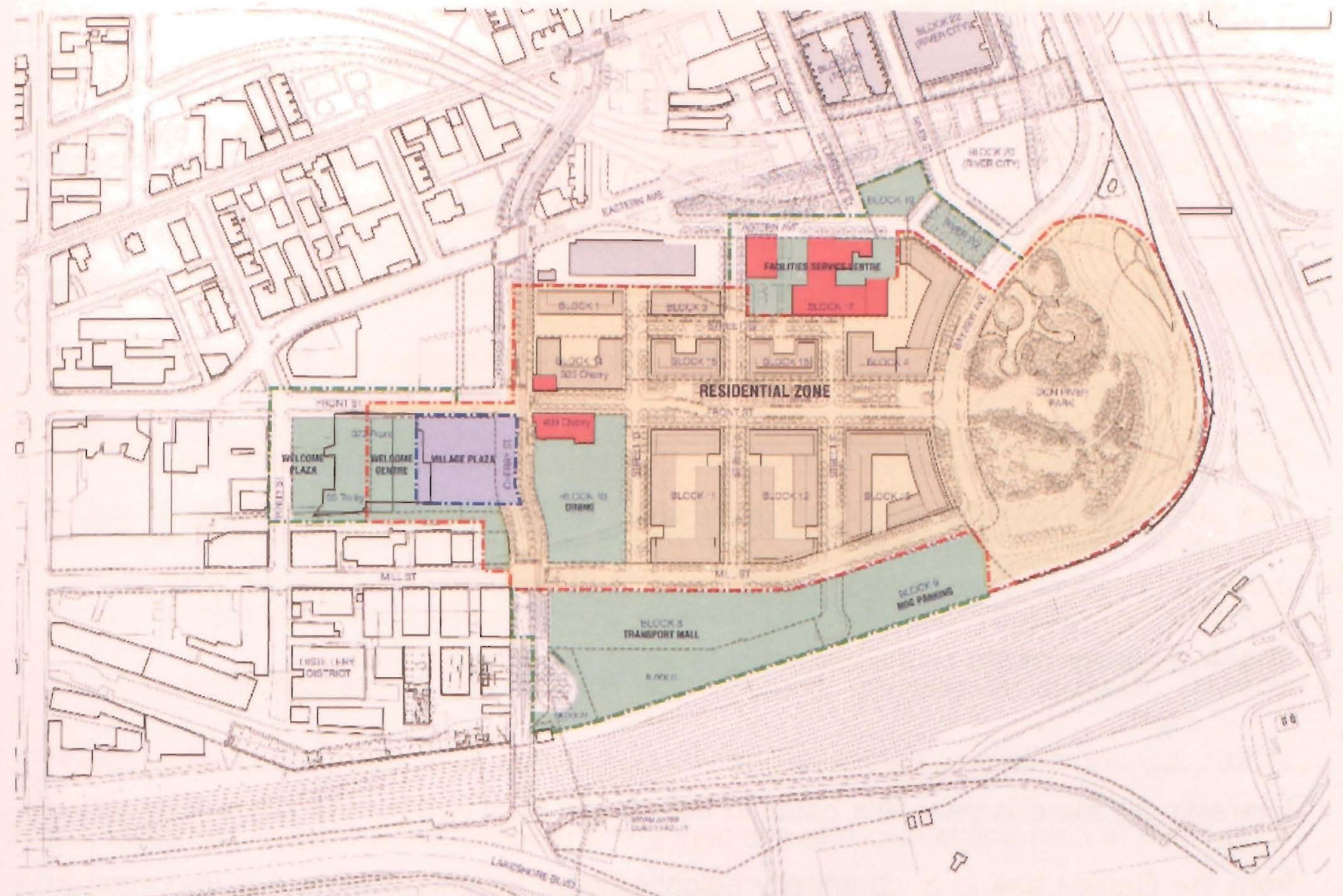

Figure 9: The Athletes' Village Site Plan

Source: (Toronto 2015, 2008)

The Village Plan (2008) outlines both long and short term visions for the site. In the short term, it is envisioned that the Village will "respect the traditions, cultures, abilities, languages and cuisines of all residents." To achieve that, adherence to specific designs, policies and practices is required. Further, Toronto 2015 hopes to provide a "quiet, safe and secure Game-time home of Olympic standards for up to 8,500 athletes and team 
officials" (Toronto 2015,2008 ). It is obvious that the Village Plan's short term visions are athlete centered.

Conversely, the long term visions focus on the legacy the Village will leave following the Games. According to the Village Plan (2008), the Village is to become "one of the jewels of the Games legacy." It is envisioned that after the Games the site will become "a community that is economically, socially and environmentally sustainable" (Toronto 2015,2008 ). Further, it is envisioned that the redevelopment on the waterfront will address a number of public policy objectives, such as reducing urban sprawl, creating new affordable housing and community sport facilities, enhancing access to public transit and reducing the environmental impacts of development (Toronto 2015, 2008). These goals are based on the visions outlined by the Precinct Plan.

Interestingly, there is very little detail in the Village Plan on how the site will transition from the Games use to a vibrant city neighborhood. For this reason, it is important to consider how the construction of the Pan American Village will interfere with the visions and guidelines set out in both the Central Waterfront Secondary Plan and more specifically, the Precinct Plan. Looking at the indicators from specific case studies will allow for a more successful post-game conversion to a highly functional, vibrant, and mixed-use neighborhood. 


\section{Indicators for Success \& Lessons Learned from Earlier Village Conversions}

Through a careful examination of the literature on this topic, it has become apparent that there are several indicators that help determine the nature of the post-game legacy left behind by an athletes' village. Those indicators will be expanded upon below, using lessons from three successful village conversions for support. A full profile of the cases can be viewed in Appendix 2. Other examples will also be cited where necessary.

\subsection{Create a Post- Game Plan}

Over the last four decades, athlete villages have evolved to serve a dual function- they accommodate athletes during sporting events and following the event are converted into an appropriate use for the rest of the city (Munoz, 1997). The conversion from village to a subsequent post-event use occurs with differing degrees of success, thereby reflecting the context and values of the host city and its planning policies (Munoz, 1997). It is important to have a thoughtful and strategic site and conversion plan in place prior to the construction of an athlete village so the transition to a subsequent use can occur smoothly and allow for the best utilization of the site (Gunderson-Hunt, 2009; Millet, 2007). The International Olympic Committee (IOC) requires specific accommodations within its athlete villages and those demands must be balanced following the Games. For example, the $10 \mathrm{C}$ requires hosts to have athletes live in densely packed, dormitorystyle housing to accommodate typically over 10,000 athletes, coaches and officials (Gunderson-Hunt, 2009; Swaddle, 2010). This design is not practical for most post-

game uses and thus conversion plans must be drafted in advance. According to Scott Beck, the president and CEO of the Salt Lake Convention and Visitors Bureau, "if there 
isn't enough forethought given" to planning for a post-game use, villages "become quite a drain on the local municipality that funds them", thereby affecting the local population (Gunderson-Hunt, 2009). According to Millet, 2007, "there is no point in building sports facilities or residential estates for the fortnight of the games if their post-Olympic use is not defined from the very outset."

Following the 1992 summer Games in Barcelona, the City experienced a successful post-game village conversion. This was in part due to expedient and thorough planning. Rather than having piecemeal development for the Games, the City focused on long term, holistic planning strategies (Coaffee, 2008). Part of its long-term strategy was to limit the amount invested in projects related to sports infrastructure and facilities and instead focus on projects that would continue to benefit the City after the Games. As such, only $9.1 \%$ of the total investment was put towards specialized sporting facilities and infrastructure (Cahyadi \& TenBrink, 2004). For the facilities and developments that were built for the Games, the Plan General Metropolitan (PGM) mandated that they have well-defined post- Game uses. This was the case for the athletes' village built at Par de Mar (Monclus, 2008). Having a post -Game plan allowed many of the desired regeneration legacies for the site to be actualized. For example, having the site become a popular tourist attraction, cultural and art centre (i.e commissioning architects/artists to create special pieces for the site) and destination within the City.

The Vancouver 2010 winter Olympic Games also had a well defined post-game plan for its village. The Vancouver planning department began preparing for the redevelopment 
of the Southeast False Creek (SEFC) site, where the village was located, several years before submitting its bid in 2003 to host the 2010 Games. As such, it already had in place the pieces it needed to produce a long term planning strategy for the sito. Obviously some changes to the Official Development Plan (ODP) in terms of the SEFC zoning needed to occur. Millennium Development, the developer in charge of constructing the village, worked with the Project Office, the City of Vancouver Planning and Engineering Departments and a variety of stakeholders, including the City of Vancouver Sustainability Office, to come up with new zoning that would represent a variety of interests and points of view (Millennium OV Properties Ltd., Merrick Architecture \& GBL Architects Group Inc., 2006).

Their rezoning submission respected the $O D P$ and balanced excellent urban design with social, economic and environmental well being. It included an encompassing evaluation of the sustainable strategies required by the ODP and provided commentary on the mechanisms and technical designs needed to meet those strategies (Millennium OV Properties Ltd. et al, 2006). As such, their submission was entirely compliant with the principles of the ODP (Millennium OV Properties Ltd. et al, 2006), making it likely that the long term vision for SEFC will be realized. It may be too early, however, to draw conclusions as the Games ended in winter 2010.

In contrast, Sydney is constantly cited as an example where no post-game plan was put in place for the conversion of its 2000 Games village (Lochead, 2006). According to Lochead (2005), "Sydney embarked upon the Olympics with supreme confidence" 
however, "behind the glass there was no metropolitan strategy" making it clear that there was not enough devotion to the aftermath of the Games (Lochead, 2006; Brooke, 2004). The original development of the Sydney Olympic Park was guided by Master Plan 1995, which defined the major planning and urban design guidelines for the site (New South Wales Government, "Sydney Olympic Park Master Plan 2030", 2010). However, it was only after the event that the short-sighted nature of this plan was realized (Lenskyj, 2008). As a result, the New South Wales Government established the Sydney Olympic Park Authority (SOPA) in 2001 to manage, plan and develop the Sydney Olympic Park (Cashman, 2008).

Under the Sydney Olympic Park Authority Act 2001, SOPA was mandated to ensure that: the Park becomes an active and vibrant town centre and a destination for cultural, entertainment, recreational and sporting events; natural heritage is protected and enhanced on the site; and any new developments carried out on the site are in accordance with best practice environmental and town planning standards (New South Wales, "Master Plan 2030", 2010). They ultimately created Master Plan 2002, a 7-10 year plan, meant to capitalize on the potential post-game legacies of the site. Again, this plan was too short-sighted, eventually leading to the creation of Vision 2025 in 2005, which built upon Master Plan 2002 (New South Wales, "Master Plan 2030", 2010).

Unlike Master Plan 2002, Vision 2025 offered guidelines for urban structure and form and mixed-uses that would allow the Sydney Olympic Park to become a sustainable and vibrant township (New South Wales, "Master Plan 2030", 2010). Subsequently, 
following stakeholder input and further refinements, Master Plan 2030 was created, building on the earlier site plan of Vision 2025 and establishing guidelines for a more compact development than previous plans suggested (Lochead, 2006; New South Wales, "Master Plan 2030", 2010). Master Plan 2030 also simplified the site by dividing it into nine district precincts, each with their own controls: Central Precinct, Sports and Education Precinct, Stadia Precinct, Sydney Showground Precinct, Parkview Precinct, Boundary Creek Precinct, Tennis Precinct, Southern Sports Precinct and Haslams Precinct (New South Wales, "Master Plan 2030", 2010).

Today the Sydney Olympic Park is on the right track, and with the addition of numerous residential units it will soon be possible to use the site to accommodate the massive population growth (approximately 1 million people) that is expected to occur in Sydney over the next 10 years (Lochead, 2006). The Central Precinct which is currently the business park, will be progressively transformed into a high density, mixed-use neighborhood with commercial offices, retail and residential accommodations; a similar transformation is to occur in the Parkview Precinct (New South Wales, "Master Plan 2030", 2010). The Haslams Precinct, which currently accommodates waste services and provides coach bus parking, will also be replaced with the development of a residential neighborhood overlooking the Olympic Park (New South Wales, "Master Plan 2030", 2010). Further, smaller commercial and retail businesses are just starting to relocate to the Sydney Olympic Park, making the site feel more complete and less massive in scale, as well as providing the critical mass for further development. 


\subsection{Ensure the Village Site is Integrated and Accessible to the Rest of the City}

In order for any urban space to be vibrant and successful, it must be accessible and integrated into the fabric of its city. The importance of accessibility to the post-game success of former village sites is best illustrated with the 1968 Mexico Olympic Games. Following its closure, the City had difficulty selling homes due to the village's inaccessible location (Pitts, 2009). The following Games, which were held in 1972 in Munich, acknowledged that, and for the first time athletes' villages began to be constructed in city centers rather than at a city's periphery (Munoz, 1997).

The Parc de Mar development in Barcelona is an excellent example of a post-game community whose success and vibrancy can be partly attributed to its accessibility and integration with the rest of the City (Carbonell, 2005). Parc de Mar was chosen as the best place to locate the athletes' village, as it was seen as a way to open up the waterfront to the rest of Barcelona (Chalkey \& Essex, 1998; Valera, 2002; Monclus, 2008). Through the removal of the railway tracks that acted as the major accessibility barrier to the site, its shape and growth pattern was altered (Chalkey \& Essex, 1998).

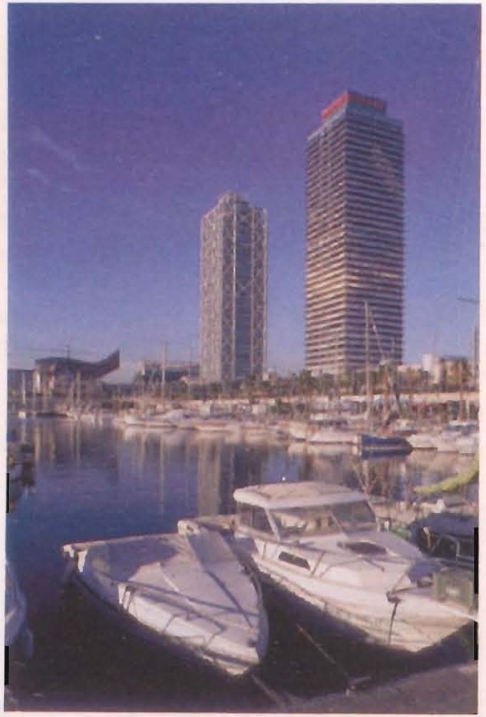

Figure 10: Olympic Harbor at Parc de Mar

Source: (Barceolona Point, 2009) Ring roads, which connected the village to four other new developments and the rest of the City, allowed the site to become accessible to vehicles (Monclus, 2008). Further, road widening projects were undertaken to accommodate the anticipated increase in vehicular traffic that would radiate from the 
site during and following the Games (Monclus, 2008). Metro stations and transit lines were constructed to and within the site to allow for non-vehicular access to the waterfront site (Carbonell, 2005; O'Connor, 2008). In terms of pedestrian accessibility, walkways were created between Parc de Mar and the historical core of Barcelona (O'Connor, 2008). The site is also accessible by water, as a new marina created the Olympic Harbor (Chalkey \& Essex, 1999).

The Sydney Olympic Park, due to its central location at the geographic heart of Sydney and between the rapidly developing Parramatta and Strathfield/Burwood corridors, is well integrated with the rest of the City (New South Wales, "Master Plan 2030", 2010). Besides its strategic location, the infrastructural legacy from the 2000 Games has helped ensure that the site is well connected via excellent road and rail access (New South Wales, "Master Plan 2030", 2010). Due to aging and high volume use, however, some deterioration has occurred to that infrastructure. Recognizing the importance of good, well maintained access routes, plans are underway to implement
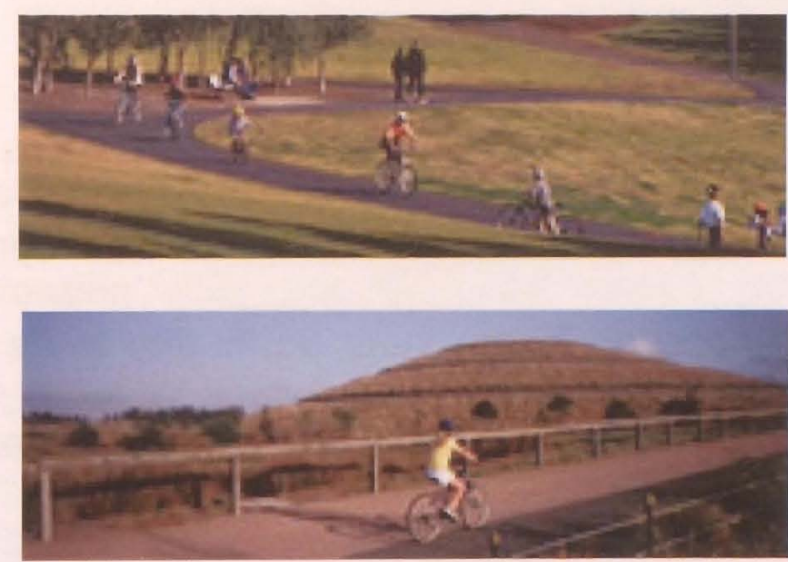

Figure 11: Cycling and Pedestrian Paths Through the Olympic Park Source: (SOPA, 2010)

travel demand strategies, road upgrades and new public transport lines during peak commuter periods to the site (New South Wales, "Master Plan 2030", 2010). Further actions have been taken to reduce auto dependency and enhance pedestrian accessibility through a modal shift to cycling and walking, by facilitating safer 
pedestrian/cyclist movement. In some areas, vehicle access is physically separated and clearly distinguished from pedestrian routes and bike lanes have been created (New South Wales, "Master Plan 2030", 2010).

The Newington community (where the athlete housing was located) is adjacent to the Olympic Park and is also very well integrated with the City and Park. Two bus routes run through the site and a ferry service is offered from Sydney Olympic Wraf to Parramatta and Circular Quay (Newington Neighborhood Association, 2011). Finally, train services connect Newington to all major stops on the Sydney Rail Network (New South Wales, "Master Plan 2030", 2010). According to Chuck Ow Lee, a current resident in Newington, he chose to live there because of the reliable transportation links between the neighborhood and Sydney's Central Business District (Brooke, 2004).

Vancouver's SEFC village site was accessible prior to the Games. According to Larry Campbell, the Liberal Party Senator representing British Columbia, he purchased a condominium unit there partly due to its "proximity to the Canada Line rapid transit station" (Baker, 2011). Despite the fact that the site is already well connected, there are further plans to enhance the former athletes' village accessibility and integration with the City. The Southeast False Creek Transportation Study, undertaken by the City of Vancouver in conjunction with IBI Group in 2002, outlines the transportation and accessibility objectives for SEFC. Its most overarching objective is to provide a wide range of transportation options that promote socially, economically and environmentally sustainable travel choices to the site and through the City (IBI Group, 2002). The 
Transportation Study's vision is to develop a transport network in SEFC that will greatly shape the neighborhood's form and livability (IBI Group, 2002). It further envisions the development of transportation and circulation systems that focus on pedestrian and bicycle paths and transit linkages that will ensure a livable and environmentally sustainable waterfront neighborhood (IBI Group, 2002). Some strategies it proposes to recognize those visions is the creation of community transit passes, car sharing programs, parking management and transit-oriented development, improved transit connections and pedestrian and bicycle infrastructure improvements - all of which contribute to the creation of a 'complete community' (IBI Group, 2002).

Recognizing the ambition of its plan, the City of Vancouver has established a program to monitor its progress and success through setting targets and establishing indicators (IBI Group, 2002). The use of benchmarks or indicators are believed to act as a form of motivation to "keep on track" with the goals that are set out in the Plan (IBI Group, 2002). This is backed up by the popular expression "what gets measured, tends to get done" (IBI Group, 2002). No reports have been published since the Games that examine the progress of the City's transit programs.

\subsection{Design the Site for Compact, Mixed-Uses}

Besides being accessible, it is apparent that a successful post-game development should be compact and involve a mix of uses. According to Coupland (1997), mixed-use communities offer a variety of potential benefits. They ensure the vitality of a neighborhood by allowing a range of activities to take place in one area. This in turn 
attracts a diverse set of users, adding to the cultural richness and vibrancy of a site (Coupland, 1997). Due to their vibrancy and constant activity, mixed-use communities are often safer than single use sites. By accommodating a range of different yet complimentary uses, such as residential, retail, commercial, recreational and open spaces, they can play off of one another, making a neighborhood more attractive to residents, businesses, shoppers and visitors (Coupland, 1997). Further, the density or "compactness" of a neighborhood is believed to influence the quality of urban life and how public spaces are used (Barcelona Field Studies Centre, 2009). In low-density neighborhoods there is a gradual process of privatization and a weak sense of community, safety and belonging, which contrasts with high density neighborhoods that form tight knit communities (Barcelona Field Studies Centre, 2009).

The development in Barcelona at Parc de Mar illustrates the importance of density and mixed-use to the vitality of a site. Parc de Mar is a mixed-use community that has become an extremely popular tourist destination due to the range of uses it offers, including beaches, art displays and high end accommodations, bars, restaurants and retail shops. However, Parc de Mar has become known as a "spectacle" or a place to visit infrequently for a short period of time, thereby preventing it from becoming as socially

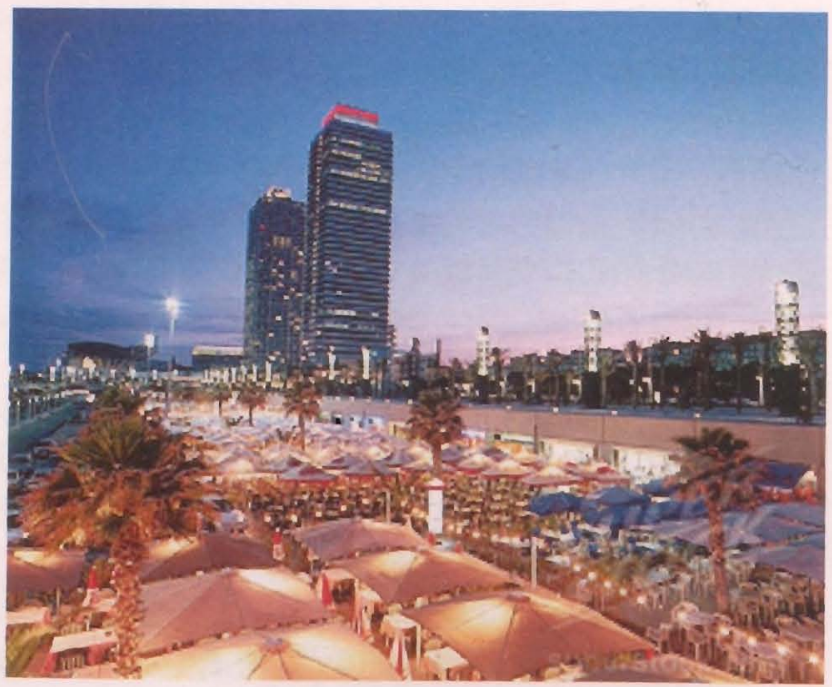

Figure 12: Mix of Uses at Parc de Mar: restaurants, office towers, hotels, open space Source: (SuperStock, 2011) 
and economically vibrant as first expected (Barcelona Field Studies Centre, 2009). This is in part blamed on the high-end nature of the neighborhood that only a small segment of tourists and the population can enjoy. It is also in part due to the density of the space. The Mayor of Barcelona, Joan Clos, has blamed the lack of "social and economic life" at Parc de Mar on low density planning (Barcelona Field Studies Centre, 2009). As it currently stands, Parc de Mar only accommodates 60 dwellings per hectare and therefore it lacks a permanent population (Barcelona Field Studies Centre, 2009). Infill development has been suggested by Clos, however, as British architect Richard Rogers points out, actualizing high density in cities where the housing market values low density is difficult to achieve (Barcelona Field Studies Centre, 2009).

In terms of the Newington suburb in Sydney, mixed-use and compact development occurred there following the Games as the athlete housing was converted into family style units (Pitts, 2009). The dense suburb contains a diverse range of housing types, including town homes and single detached dwellings. This means that the site is able to accommodate a wider range of people from varying socio-economic statuses, income levels, and age (Kapadia, 2008). Further, there is a school, retail node and commercial area located within Newington (Newington Community Association, 2011). It is that type of mixed-use that attracted Monica

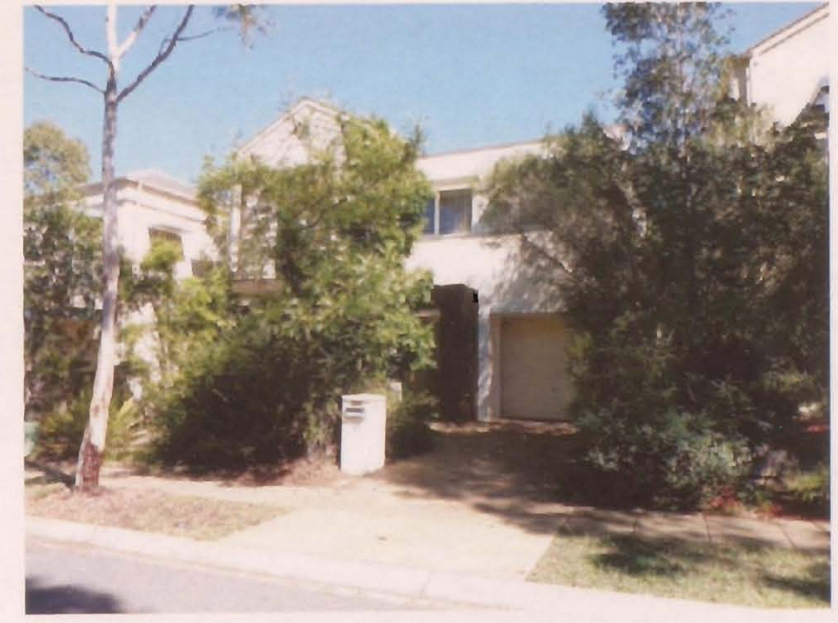

Figure 13: Single Detached Neighborhood in Newington. Source: (REA Group, n.d) 
Debickas and her family to Newington. They were not drawn there by the Olympic glamour, but rather by their desire to have "a beautiful place to live...away from pollution" in a friendly, accessible and family focused environment (Campion, 2010).

Using Newington as a model, SOPA has begun to recognize the importance of having a mixed-use community in the Sydney Olympic Park. According to Master Plan 2030, it intends to eventually convert the Park into a corridor that contains residential, educational, entertainment, recreational and retail uses (Lochead, 2006; New South Wales, "Master Plan 2030", 2010). The plan acknowledges that the site will need to offer a solution to Sydney's population growth, and in the future hopes to accommodate a residential population of 25,000 and a daily working population of 24,500 (Lochead, 2006). As mentioned earlier, Master Plan 2030 divides the site into nine precincts, of those three are to become mixed-use residential areas (see p.35). The first to undergo that change is the Central Precinct, which will be progressively converted into a "high density, mixed-use neighborhood with commercial offices, retail and residential uses" (New South Wales, "Master Plan 2030", 2010). Once the precincts become more mixed in use, the Sydney Olympic Park will be more socially and economically sustainable.

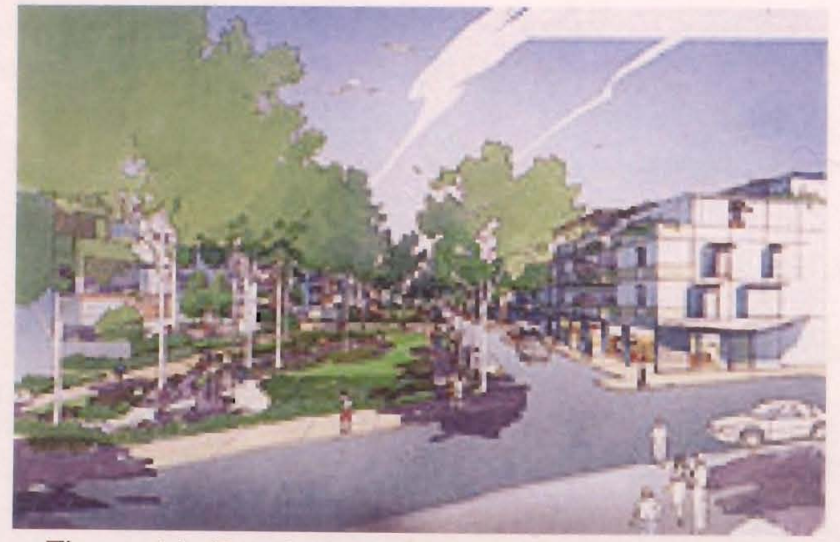

Figure 14: Rendering of future Haslams Precinct: mix of uses Source: (SOPA, 2010) 
In the SEFC neighborhood, according to the Official Development Plan, the major land use objective was the conversion of a former "brownfield site" into "a highly livable, sustainable, mixed-use environment" (City of Vancouver, 2007). Eventually SEFC will consist of a family residential neighborhood with the supportive services required for a complete community (City of Vancouver, 2007). The intention of the ODP was also to have a mix of residential accommodations and tenure types that would attract a range of ages, socioeconomic statuses and family structures. Its original targets however have been altered due to circumstantial pressure. The housing development at SEFC is a currently a contentious issue in Vancouver because of people's differing perception on

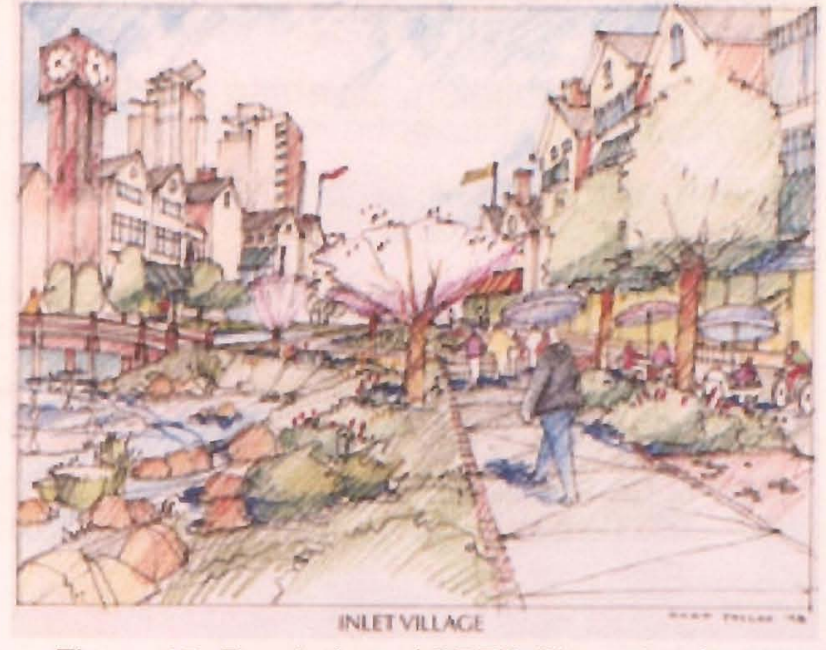

Figure 15: Rendering of SEFC Site: mix of uses Source: (City of Vancouver, 2007) what makes an appropriate housing mix. Further, the majority of residential units have not been occupied, which in turn has discouraged retail and commercial businesses from locating in the former athletes' village (Klassen, 2010). According to Heather Eddy, who recently moved into a rental apartment there, "I'm scared to walk down the streets at night" (Inwood, 2010). This highlights how mixed-use communities can enhance one's sense of safety, sense of belonging and well being. The City is currently working on developing a strategy to sell the units and bring vibrancy to the site. 


\subsection{Plan for the People, not Tourists}

One of the many reasons cited for hosting a mega-event is that they offer the opportunity for cities to gain international acclaim and notoriety, thereby attracting investment and tourism and strengthening local pride. However, planning for a spectacle can undermine the needs of the people living in the host city. One of the many concerns expressed by anti mega-event activists is that events come at the expense of the local population, diverting funding away from the real issues, such as education, health and welfare programs (Lenskyj, 2002; Chalkey \& Essex, 1998). Often, many complain that hosting a mega-event is similar to subsidizing affluent consumers and visitors at the expense of local, underprivileged populations as such events put financial strains on social services, education and housing provisions (Chalkey \& Essex, 1998).

This is particularly true for athlete villages which are considered to be one of the most expensive venues to be built, and which following the Games are enjoyed by a generally smaller segment of the population compared to sport facilities. According to Andranovich et al. (2001), "providing resources [public or private] to build a tourist bubble...in the face of increasing urban poverty, raises the question- to what extent are local governments responsible for the everyday conditions faced by local residences?" The focus then, should not be on those who visit or who can invest in the city, but rather on what the local people need and how the event can allow their needs to be met (Andranovich et al., 2001; Lenskyj, 2002). 
The use of a coherent urban strategy and vision that is accepted by the local population is one way to ensure that an athletes' village leaves behind a positive legacy and meets the needs of a city's citizens (Millet, 2007; Lochead, 2006). Including the local population in the decision making process enables them to form an attachment to the site, thereby enhancing its vitality and their commitment to it (Cashman, 2008). In Barcelona, urban interventions related to the Games were made with a focus on local priorities and needs. The Village was located specifically on underutilized waterfront land because the local population expressed their desire to stimulate development and regeneration in that area (Coaffee, 2008); they saw the potential benefit that could be gained by thoughtful development there (Monclus, 2008). They knew that once the City was opened up they would be rewarded with an "urban front open to the Mediterranean" (Monclus, 2008).

In Vancouver, the engagement of the community through consultation meetings was a major part of developing and working towards the vision for a sustainable, mixed-use neighborhood at SEFC, as outlined in the ODP. Numerous open houses, public workshops and hearings were held to get input from key stakeholders, adjacent business improvement associations and residential associations (The Challenge Series, 2010). The local citizens and stakeholders expressed their desire to see a vibrant, ecologically sound and socially cohesive community on the site. These visions, despite the Olympic bid and other planning pressures, remained a guiding factor through the entire planning and construction process for the village (The Challenge Series, 
2010). Allhough there are some shortfalls regarding affordability and housing choice, the SEFC development still respects many of the local population's visions.

The case of Sydney differs from what occurred in Barcelona and Vancouver. Rather than having a full public consultation process for developing the visions and goals outlined in Master Plan 2030, only key stakeholders were included in the consultation process (New South Wales, "Mlaster Plan 2030", 2010). One possible explanation for this is that full public engagement would have further slowed the post-game transition, highlighting the inadequacies of prior plans for the site. Despite their exclusion in the post-gamo design and visioning for the future Olympic Park, the public was included in deciding how the contaminated lands at Homebush Bay should be reclaimed. They were asked to reflect on whether they would prefer for the waste to be removed and stored elsewhere or be capped on location (Sydney Olympic Park Authority, 2010). This resulted in positive feelings towards the site, and a sense of ownership towards it.

Bosides including the public in the visioning process for a site, ancther way to ensure that the local population benefits from a post-garrie village is to consider to what extent the cost of maintenance and construction will be placed on the local population (Lenskyj, 2002). It is often difficult to predict how much a village will cost to construct as unforeseen expenses may arise, thereby placing an extra burden on taxpayers. This was seen with the 2004 Athens summer Games (Lenskyj, 2002). Significant cost overruns were experienced die to the increased security measures needed as a result of the $9 / 11$ terrorist attacks (Lenskyj, 2002). Aithough it may be difficult to plan a 
perfectly balanced budget, there are areas where it is possible to control for the burden that will be placed on local taxpayers, ensuring that the Games are not regressive.

One way to do this is by being logical about the design of an athletes' village rather than being over ambitious (Gold \& Gold, 2008). It is well known that luxury developments often do not fare well following the closure of a mega-event. Jacque Rogge, the president of the IOC, warns hosts about the danger of luxury developments which he says become costly "white elephants" in terms of construction and maintenance cost. Futher, monumental scaled and highly specialized developments often do not benefit the majority of the population (Cashman, 2008). It is thus more practical to design and develop a viliage that is based on a simpier, more practical design.

Barcelona's Parc de Mar is an excelient exampie of what happens when a viliage is based on luxury deveiopments. The cost of living and even visiting the former athletes' viliage is prohibitive in part because of the gentrification of the site and in part due to the immense luxury deveiopments there (Kapadia, 2008; Lenskyj, 2008). The majority of the original population living on and around the area were forced to leave due to astronomical price increase in the cost of living there. Those people displaced included low income workers, the eiderly and Roma or gypsy populations. This displacement led to the erasure of Earceiona's historic Earrio Chino (Chinatown) and hid its working class struggies (Lenskyj, 2002). Further, the reighborhood is exclusive, with housing prices exceeding those which the local population can afiord. Much of the housing on the site is now being marketed towaras the Eritish as holiday housing (Kapadia, 2008). 
One of the major issues facing the Sydney Olympic Village following the Games was the monumental scale of its buildings (Lochead, 2006). Although larger scale buildings are appropriate for mega-events, they are less suitable for daily visitors, residents and tourists, as they make the space vast, alienating and unsafe. According to Lochead, (2006), the

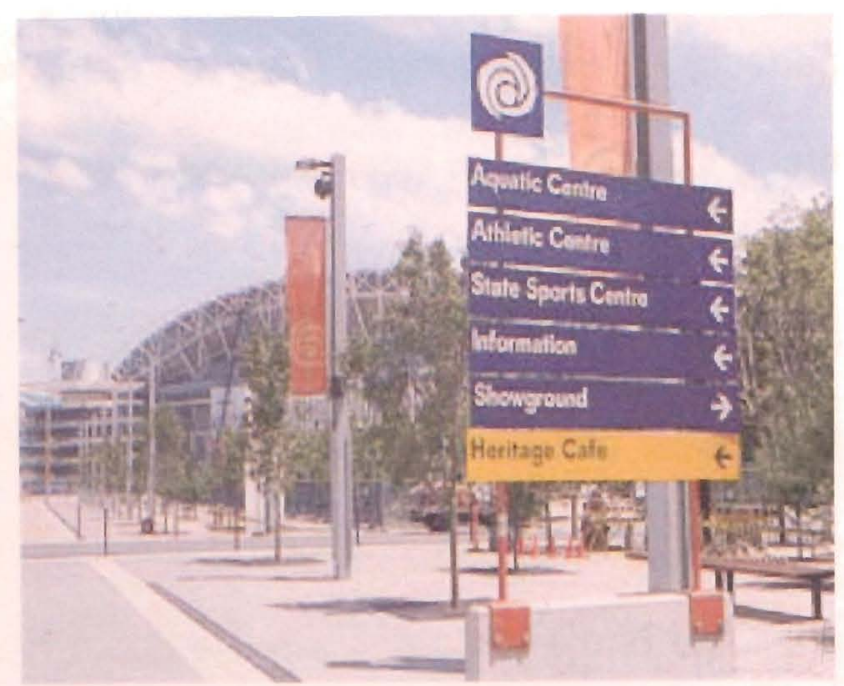

Figure 16: The Monumental Scale of Sydney Olympic Park

Source: (Plan Book Travel Australia, 2011)

Olympic Boulevard, which is bordered by light towers and monumental buildings for up to $1.5 \mathrm{~km}$ "can be a duaunting prospect when not accompanied by a crowd." As a result, the Park has been having trouble attracting tenants to occupy the site. The existing structures need to be superimposed with "finer grain", smaller scale buildings and public spaces to make the site more functional, which will be costly (Lochead, 2006). Further, large buildings are extremely expensive to maintain, especially if they are low occupancy. This was the case with Monteal's Olympic stadium (Swaddle, 2010). In contrast, Newington was built specifically with a neighborhood scale. As such, converting the athlete housing to permenant units was not as costly.

The SEFC development in Vancouver, like in Sydney and Barcelona, is also facing issues pertaining to its financial impact on the local population. Much of the controversy began in 2006 when Millennium was put in charge of the development. The City held the title of the land, and as such, Millennium was unable to secure financing from the 
Canadian banks, forcing it to seek funding from the American hedge fund, Fortress Investment Group, instead. In return, they needed a loan guarantee from the City, thus putting pressure on Millennium to price their condos at over $\$ 1$ million per unit, a significant cost, especially as the recession hit. Unable to sell the majority of the condominiums, the City had to help Millennium, which defaulted on its loans (Baker, 2011). Currently, fewer than half of the housing units have been sold and commercial businesses are reluctant to locate at the site; as a result and the City's taxpayers are now being burdened with owing $\$ 750$ million for the project (Baker, 2011). This is a significant issue as the number of affordable housing (Plan Book Travel Australia, 2011) units within the development has been cut by over $50 \%$, yet the majority of units remain vacant. 


\section{What can we Expect for Toronto?}

The following section will link the above indicators to what is planned for the WDL following the Games, based on the Precinct and Village Plans. This will allow speculation as to what the post-game legacy of the site could be.

\subsection{Create a Post-Game Plan}

It is clear, as demonstrated in section three, that a thorough, well considered post-game plan exists for the WDL, despite its interim use as an athletes' village. Over the past several years, the site has undergone extensive visioning and plarıning, resulting in the creation of the award-winning Precinct Plan. According to the Pan American Village Plan (2008), the development of the WDL was to proceed regardless of whether Toronto won the bid to host (like in Vancouver), which illustrates that a strong, long-term site plan and vision exists. This contrasts to what happened in Sydney following the Olympics.

Beyond just having a strong and comprehensive post-game plan, significant links exist between the Precinct Plan and the Village Plan, as the Village Plan is based on the principles of the Precinct Plan. That link will help enable a smooth post-game transition. The connection between the plans are most apparent when examining the intended legacy of the Village which includes enhancing the accessibility of the site by connecting it to public transit, the creation of affordable housing and providing future residents of the site with high quality sport facilities and amenities (Toronto 2015,2008 ). 


\subsection{Ensure the Village Site is Integrated and Accessible to the Rest of the City}

As mentioned earlier, it is the intention of the Precinct Plan to make the West Don Lands community more accessible to vehicles and pedestrians alike. To do so, the site will need to be opened up to the rest of the City. This will involve the creation of new vehicular, transit and pedestrian access routes. To further enhance the accessibility of the site, the WDL will also need to be perceived as being legible and integrated with the rest of the City. The Precinct Plan outlines various methods to do so, however, it is still unclear how the presence of the Athletes' Village on the site will affect those plans. For this reason, special attention should be focused on ensuring the accessibility guidelines outlined in the Precinct Plan are followed so that its accessibility goals can be easily met in the future.

In terms of integration, rather than applying a single scale of development across the site, which would lead to a monotonous landscape, a variety of scales and textures will be used to diversify the precinct and blend it with the rest of Toronto (WTRC, 2004). The Precinct Plan proposes one way to achieve this is to have the unique qualities and elements from surrounding neighborhoods woven into the design of the site, thus creating a "rich tapestry of unique places" (WTRC, 2004). A collection of old and new masonry buildings will extend east from the Distillery District along Mill Street, bringing loft style living and live/work opportunities to the WDL. Front Street will be extended from the Old Town of York to create a lively urban core in the WDL with shops, restaurants, offices and residences. River Street will be extended south, bringing the character of Corktown's mid-rise buildings and townhouses into the neighborhood. Finally, the concept of condominium blocks on boulevards, such as those found in St. 
Lawrence and the Old Town of York, will be incorporated into the site (WTRC, 2004). These measures of integration and diversification will allow the WDL to become cohesive with the rest of the City but are not mentioned in the Village Plan.

To create legibility and cohesion within the site, strict design and development controls will be implemented, such as requiring buildings to be oriented to the perimeter of their blocks. Specific constraints for view corridors, building setbacks, important landmarks and heights will be implemented to create additional cohesion in the neighborhood, as outlined in the Precinct Plan (WTRC, 2004). The height limit for most buildings will be eight stories, with taller buildings being permitted at important intersections, along Front Street, and at certain locations around the Don River Park. The north/south streets that extend from Corktown and into the WDL will have heights and scales in line with Corktown, at approximately four storeys (WTRC, 2004). The Village Plan contains some apartment and townhouse sketches, with town homes being three levels with a terrace and apartment buildings being between six and nine levels with a terrace (Toronto 2015, 2008).

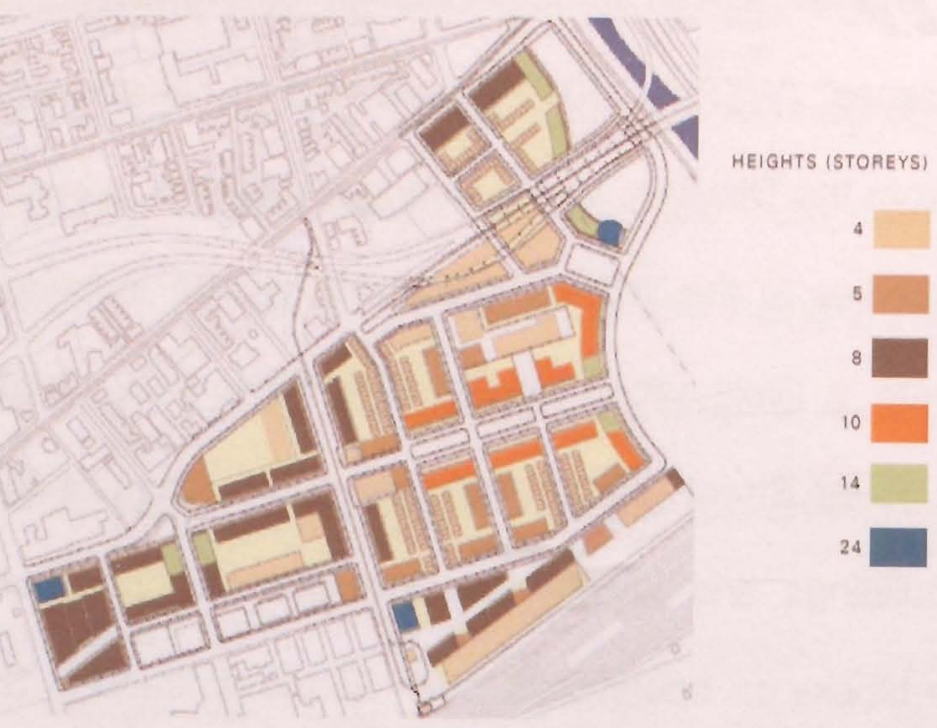

Figure 17: Building Heights in Storeys Source: (WTRC, 2004)

As illutrated in the Precinct Plan: these massings are complementary to what is being proposed in the Village Plan. 
To achieve vehicular accessibility, several changes are set for the road networks within and around the site. First, although the WDL are well connected in the east and west direction, the Precinct Plan recognizes that the north/south connections are weak, as the only north/south streets through the site are Cherry Street, Sumach Street and Bayview Avenue. To improve the north/south connectivity, Bayview Avenue will be realigned to form the western edge of the Don River Park (WTRC, 2004). The realignment process has already begun (Lavoie, 2011). To accommodate the congestion that is expected on the commuter roads around the site upon full build-out, new routes are to be created. River Street will be extended from King Street East to Eastern Avenue, Bayview Avenue and River Street will be closed under the Queen Street Bridge, and several new local streets will be built to accommodate the increase in traffic (WTRC, 2004). Finally, the interior roads of the site are to be improved, and in some cases completely rebuilt, due to their deterioration and the poor connectivity (WTRC, 2004).

Not only will the site to be opened up to vehicles, according to the Precinct Plan, it is also to be made accessible to pedestrians. In order to be consistent with the City of Toronto's transportation and sustainability objectives and Waterfront Toronto's vision for the waterfront area, the internal roads of the site will take on a more pedestrian and cyclist friendly character, allowing for the safe and convenient movement of people (WTRC, 2004). One suggestion to achieve this is through the construction of Woonerfs, European style, pedestrian oriented streets that eliminate the distinction between sidewalk and road. They create a public space that can be shared by pedestrians, 
cyclists and low speed motor vehicles. To further enhance pedestrian flows within the WDL, bike lanes on major arterial roads, cycling and walking networks within Don River Park and the improvement of several trails will be a major construction focus (WTRC, 2004). To improve pedestrian and cyclist accessibility to the WDL from the rest of the City, several physical barriers, such as the Don River and the railway yards, will have to be overcome. To do so, the Precinct Plan proposes the construction of a combination of bridges and landscaped underpasses. A pedestrian tunnel, for example, is proposed for below the sweep of the Bala rail line, which will join the Don River Park with the Don River and Lakeshore Trail systems (WTRC, 2004).

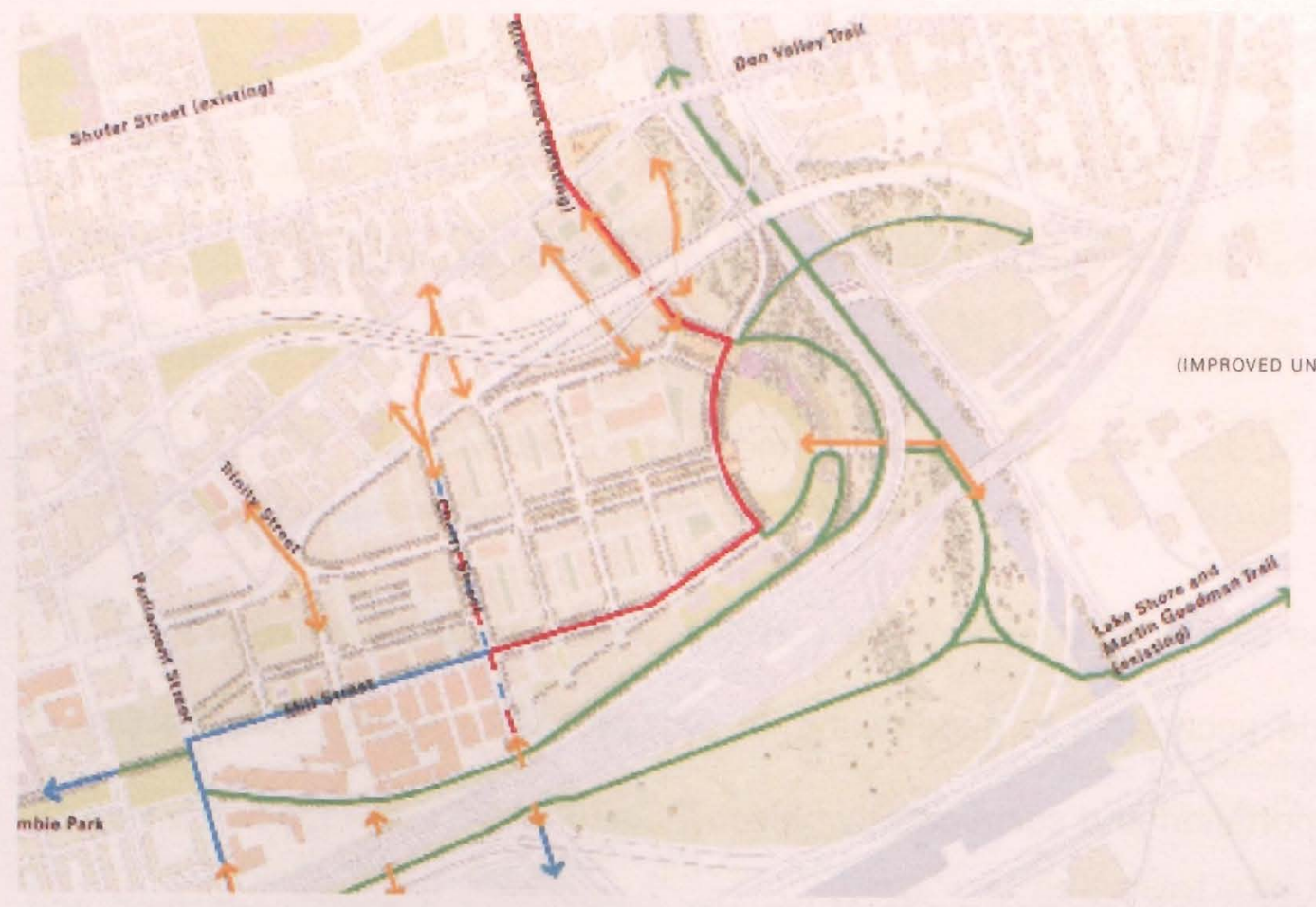

Figure 18: Pedestrian Accessibility Map Source: (WTRC, 2004)

Finally, the importance of enhancing transit accessibility to the WDL is recognized. Although the site is currently well positioned in terms of transit connectivity due to the presence of the King and Queen streetcar line, the Precinct Plan recommends further 
streetcar extensions and the creation of an exclusive streetcar line along Cherry Street (WTRC, 2004). In 2008, a Transit Environmental Assessment was approved for a new streetcar line along Cherry Street (Waterfront Toronto, 2010). Eventually it is expected that the entire WDL will be a five minute walk to any given transit stop (WTRC, 2004).

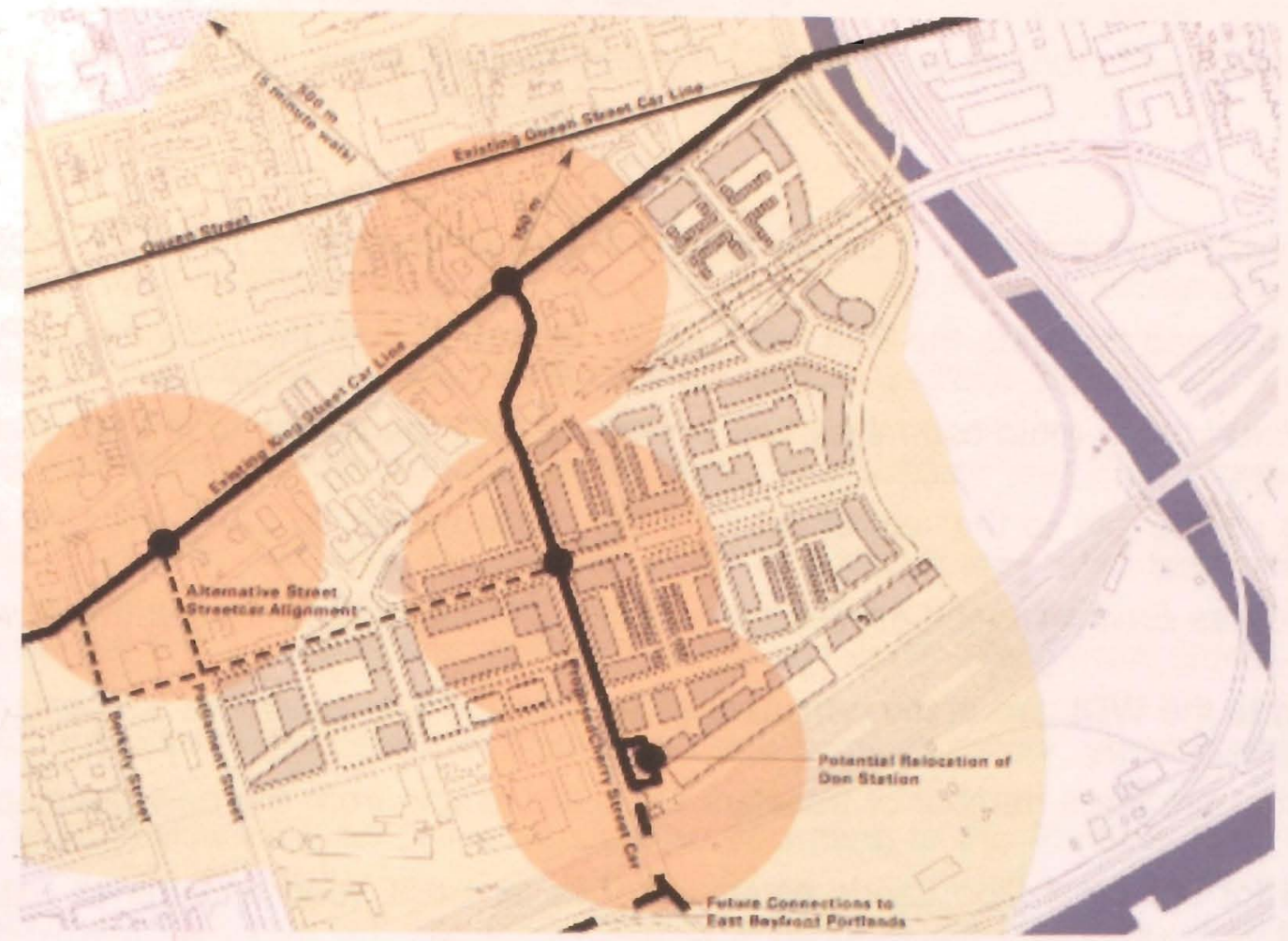

Figure 19: Transit Accessibility Map

Source: (WTRC, 2004)

In line with the Precinct Plan, the Village Plan also intends to have the site become more accessible to pedestrians, transit and vehicles, although it focuses more on external rather than internal connectivity. Accordingly, the Village will be made accessible through the creation of links to local roads, highways, express trains and public transit. This will allow visitors and athletes to easily access the WDL (Toronto (WTRC, 2004) 2015, 2008). A transportation mall will be built in the southern portion of the site and act as a hub for all the transit within the Village and between the Village and 
other sporting facilities throughout the GGH. According the Precinct Plan, however, the proposed site of the transportation mall is meant for parks and open spaces. The internal accessibility of the site will be predominantly focused on pedestrian movements. As part of the access plan, the Village will be made accessible through "numerous pedestrian pathways and bicycle paths" that will "connect the areas within the Pan American Village" (Toronto 2015, 2008). Those paths will persist following the Games.

It is apparent time and effort has been spent to ensure that the WDL will be accessible both during and following the Pan Am Games. On top of both the Village and Precinct Plan, Waterfront Toronto commissioned a report in 2008 pertaining to the importance of opening up the site to the rest of the City via public transit. In the West Don LandsTransit Class Environmental Assessment (2008), it is recognized that all transit service provided to the WDL are at the periphery of the site and are "beyond a convenient walk for most of the large number of travelers expected to and from the new developments planned for the West Don Lands community." As a result, road and transit extension projects are underway. With the pending Games, the construction timeline of these projects will likely be pushed forward in order to service the Village in 2015 , as is the case with the Pearson International Airport- Union Station line. This enhances the probability that that the post-village development will become a vibrant part of Toronto.

\subsection{Design the Site for Compact, Mixed-Uses}

As mentioned earlier, compact, mixed-use communities are often prosperous. Achieving a successful mixed-use neighborhood is one of the major visions outlined in the 
Precinct Plan, which aims to accommodate a range of retail, commercial and employment uses on the site, along with heritage, recreational and open spaces (WTRC, 2004). As illustrated in section four above (p. 38), however, achieving a truly mixed-use community is often difficult. Despite that difficulty, the Precinct Plan depends on the provision of mixed-uses to ensure the social and economic vitality of the neighborhood following the Games and into the future.

In terms of commercial uses, according to the Precinct Plan, approximately 1 million square feet of commercial space will be dispersed throughout the site, with the majority being located in a node around the intersection of Cherry and Front Street (WTRC, 2004). This complements the Village Plan, which indicates that the central retail/ commercial hub will be located in the "International Zone" along Front Street, mainly at the Cherry Street intersection. Within that zone, a media centre, guest dining, banking and retail facilities will be provided. Further, according to the Precinct Plan, office and employment buildings will be constructed in areas that are well connected to existing transit services, specifically along King and Parliament Streets, and a live/work area will be developed along Mill Street. These uses are beyond the Village boundaries and therefore will likely not be impacted. It is expected that a minimum of 4000 jobs will be created on the site (WTRC, 2004). It is this mix of employment uses with economic benefits that will help to ensure the economic vitality of the site into the future.

In terms of residential uses, the Precinct Plan specifies that a range of residential units with different tenure types will be built in the WDL, thereby accommodating people of various ages, economic statuses, backgrounds and lifestyles. Larger housing units will 
be constructed for families and affordable rental and ownership housing will be provided for the elderly and government workers. Subject to program funding, $20 \%$ of the units constructed will be affordable rental housing (approximately 1,200 units) and $5 \%$ will be low end of market housing (WTRC, 2004). The provision of affordable housing in the WDL will be necessary to alleviate some of the housing and affordability issues the City is currently facing. To enhance the attractiveness of living there, a variety of community facilities will be built, including schools, daycare and community centers, emergency services and parking services (WTRC, 2004).

In the Athletes' Village, residential use will be the largest component of its design. According to the Village Plan, all core services will be located within a five minute walk from the athlete housing, thus allowing the Village to be compact in form. This complements the Precinct Plan's vision of having a sustainable, compact neighborhood on the site. However, although the Village Plan mentions that the athlete housing will be converted into permanent housing after the Games, it does not say how it will be done, how much it will cost, and how long it will take. If a mix of housing and tenure types are not provided following the Games, it could impact the Precinct Plan's vision to be make the WDL socially sustainable.

Measures are already in place that are meant to ensure that affordable housing on the site is actualized. The team that wins the request for proposal to develop the Village will have to demonstrate that it respects the affordability targets for the WDL. A request for qualifications to own and operate the affordable homes in the WDL will be issued by 
Infrastructure Ontario to the non-profit housing sector in spring 2011, resulting in the shortlisting of teams based on their management experience, capacity and financial stability to own and run affordable housing. After the RFQ, a request for proposals will be issued to select the winning team (The Co-operative Housing Federation of Canada, n.d).

Parks, open and recreational spaces will be provided throughout the site, according to the Precinct Plan, thereby facilitating social interactions and active use in the community. The largest parkJopen space will be the 18 acre Don River Park. The Park will be the centerpiece for the WDL, and will be a destination for the entire City, with streets radiating from its centre (WTRC, 2004). It will contain a variety of plant species, paths, conservatories, and active and passive recreation space as well as a man made flood control measure, which has almost been fully constructed. To the east of the flood control berm, a portion of the Park will reflect the characteristics of a marsh delta (WTRC, 2004). The Village Plan also includes the presence of the Don River Park. It envisions it to be a space where athletes will be able to practice their sport and enjoy active and passive recreation activities. This indicates that the Don River Park will not be compromised by the temporary Athletes' Village.

Along with the Don River Park, according to the Precinct Plan, there will be numerous smaller parks/open spaces throughout the site totaling 25 acres (WTRC, 2004). Each will fall within one of four categories: areas of natural regeneration associated with the Don River; passive parks containing walkways, gardens and informal green space; 
active recreation green space for field sports; and finally, urban open space such as plazas and parkettes (WTRC, 2004). These parks will create open and naturalized areas in the neighborhood, giving the site a unique sense of place (WTRC, 2004). In contrast, the Village Plan does not discuss the presence of such parks, leading one to question whether the ambitious allocation of parks in the WDL will be fully realized.
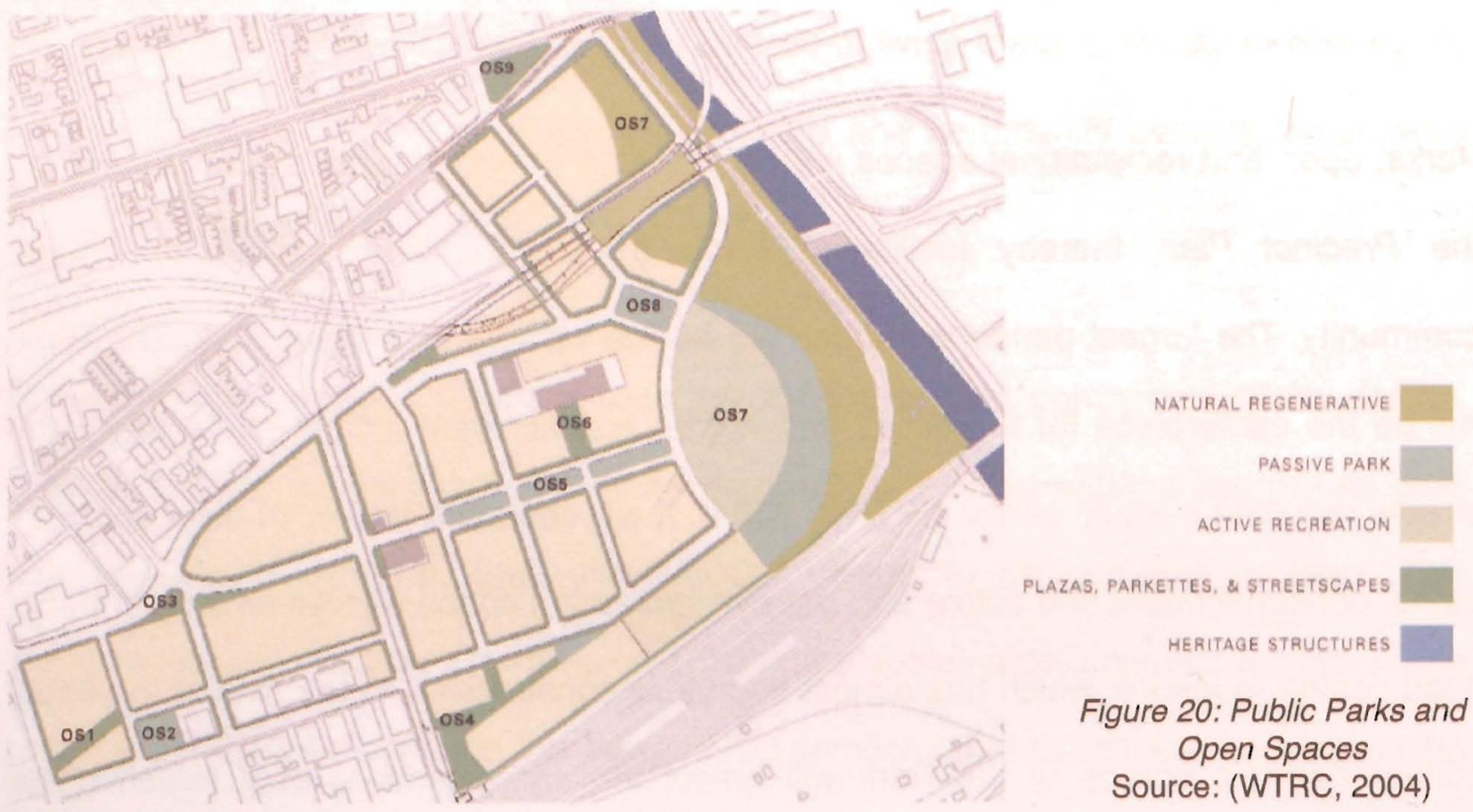

Finally, the Precinct Plan places great emphasis on retaining the heritage features and uses of the site, thereby making it an interesting place to live, work and visit, and further enhancing its social sustainability. In terms of natural heritage, the essence of the site as a river delta will be retained by incorporating numerous parks into the neighborhood as discussed above (WTRC, 2004). For built heritage, designated buildings will be integrated with new structures and strict guidelines will regulate the type of construction that occurs around them (WTRC, 2004). Further, the streetscape will connect to the sites history; for example, tree covers will be made of steel grids to pay homage to the 
industrial past of the WDL and certain elements from the surrounding historic neighborhoods will be brought into the site, such as the narrow streets from Corktown (WTRC, 2004). In contrast to the Precinct Plan, there is very little mention of how the built heritage features of the site will be respected in the Village Plan.
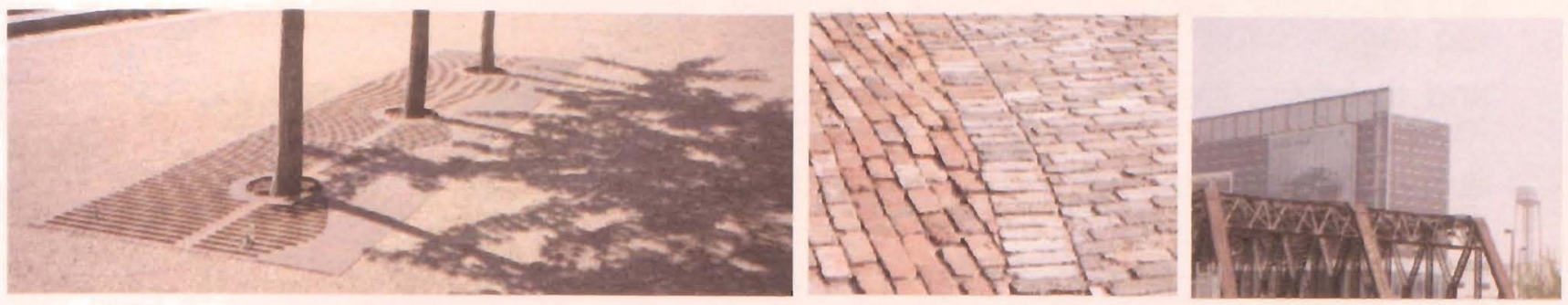

Figure 21: Built Heritage Features to be Incorporated into the Site From left: steel tree covers; brick gutter; steel infrastructure (bridge)

Source: (WTRC, 2004)

The similarities between the Precinct Plan and Village Plan regarding the location and presence of key features, such as the Don River Park, residential dwellings and the central commercial nodes is a positive indicator that a mixed-use community can result on the WDL following the Games. This is because those similarities will make the postgame conversion easier as opposed to having to completely redesign the site. It also eliminates the likelihood of an overly luxurious development, as the units will need to be functional both during and after the Games. Further, because there are no major massive structures, the scale of the Village will not be prohibitive to converting the site into a residential community. However, there are also some discrepancies between the Village and Precinct Plans relating to how the heritage and smaller parks will be treated. This will require a closer examination. 


\subsection{Plan for the People, Not Tourists}

A great deal of importance was placed on devising a development strategy for the WDL that was accepted and embraced by the local population. Key stakeholders, community groups and the general public were encouraged to participate in meetings, focus groups and charettes, and their feedback was used to develop visions and goals for the site and to inform the Precinct Plan (WTRC, 2004). The ideas and feedback generated during the consultation process is meant to guide the future development of the WDL, which is similar to what was done in Vancouver.

The first public meeting was held on December 3,2003, to obtain from the public an understanding of the perceived strengths and weaknesses of the site and its context within the rest of the City (WTRC, 2004). The information gathered from that meeting was used by the consultant team to create a set of design principles for the site. Those principles were then presented at another stakeholder meeting on January 7,2004 , and the public was encouraged to share their thoughts and feelings about them (WTRC, 2004). Finally, between February 9th and 12th a design workshop was held and the consultants presented the design alternatives and solutions based on earlier feedback. The public was asked to register their opinions and preferences for the various options and that information was used by the consultant team and City Staff to develop the final Precinct Plan (WTRC, 2004). Most of what the public wanted was incorporated into the Plan (Lura Consulting, 2004). 
This process of incorporating feedback from the public in the planning and design process was absent in the development of the Village Plan. Although public consultation may not be necessary for the Village Plan, the public may have been able to come up with some valuable insight and ideas. Due to the time and effort that went into the development of the Precinct Plan, it will be important to ensure that those visions put forward by the public and key stakeholders are respected despite the temporary use of the site as an athletes' village. It is likely that this will happen, as deviating from the Plan may lead to public backlash that the City will want to avoid, especially if fewer than promised affordable housing units are provided. In Vancouver, that broken promise has had political ramifications as Mayor Sam Sullivan of the Nonpartisan Association Party was voted out and replaced by Mayor Gregor Robertson of the rival Vision Vancouver Party (Baker, 2011). Vancouver has also seen numerous public protests, the biggest being "tent city" protest. Waterfront Toronto overseeing the development of the WDL site and the presence of a design review panel will help ensure their needs as well as the public's needs are met.

In terms of cost management, the $\$ 1$ billion Village will be funded via Infrastructure Ontario's Alternative Financing and Procurement (AFP) model. Under this model, the private sector finances the construction of necessary infrastructure, assuming the risks associated with financing, designing and building the project (Lavoie, 2011; Infrastructure Ontario, 2010). This model will inherit private-sector efficiencies, expertise and ingenuity thereby lowering the burden on taxpayers, especially when compared to government funded projects (Infrastructure Ontario, 2010). AFP lowers cost and 
schedule overruns, ensuring that projects are built on time and on budget, and builds high quality infrastructure that is durable and sustainable over time, rather than facilities that are impractical and daunting in scale. Further, AFP bestows appropriate control and ownership to the public (Infrastructure Ontario, 2010). Although the cost of funding the Games has increased, the majority of these expenses are due to the soil remediation required for the proposed Aquatic Centre in Scarborough and inflation, none have been formally linked to the Athletes' Village. This demonstrates the success so far of the AFP model in limiting the effect of the development on the local population. 


\section{Recommendations and Considerations}

Based on the four indicators illustrated above, it is likely that the temporary Athletes' Village on the WDL will not significantly alter the visions and goals the Precinct Plan aspires to achieve. It is important however that certain steps and measures be taken to ensure that the current trajectory does not change. Drawing on the best practices of the three case studies (Barcelona, Sydney and Vancouver) and from other mega-events, those measures are described below.

\subsection{Recommendations}

- Ensuring that the public remains involved throughout the development of the Athletes' Village and the WDL community will be important. According to Rudy Rivera, of RJ Rivera \& Associates (2002), ensuring that social equity issues and public concerns are properly addressed in development projects requires the use of existing and innovative techniques of public notification and participation. This can be done in a variety of ways. For example, public meetings can be held at the various stages of implementation for both the Village and WDL community, More innovative techniques that draw a wider population can also be used, such as the creation of a public involvement website. This will allow people who are unable to attend public meetings to be included. The continuous involvement of the public in the development process can act as an additional safegaurd, thereby ensuring that the ideals of the Precinct Plan are met by giving the public an avenue to express thier concerns and ideas. It will also help with making future residents of the site happy by meeting their needs. Enabling public involvement should be done 
through a joint effort with Toronto 2015 and Waterfront Toronto. The facilitator who was used in the Precinct Plan consultation process, Lura Consulting, should be used again as many of the public participants are familiar with their methods.

- Continuous monitoring of the development of the Athletes' Village will be necessary to ensure that it does not gradually deviate from its anticipated legacy and the goals of the Precinct Plan. For example, the goal of integrating the site with surrounding areas and its ambitious greenspace targets should be monitored, as well as the affordable housing targets. One way this could be done is through benchmarking. Benchmarking allows for better development by enabling planners to measure how a project has changed over time and guides appropriate actions by setting attainable targets (Hemphill, McGreal \& Berry, 2004). This will also help the project stay on budget. The monitoring should be carried out by both Toronto 2015 and Waterfront Toronto independently, not only because they are familiar with the Plans, but because the separation of power can act as a system of "checks and balances".

- It will be important to devise a strategy outlining how and how long it will take to convert the facilities used in the Athletes' Village into more permanent uses. This forethought will allow for better budgeting and building design and enable a smoother transition from an athletes' village to a well functioning, vibrant community. This should be done in cooperation with Toronto 2015 and Infrastructure Ontario, along with the team that wins the request for proposal (RFP) 
to design, build and finance the Village. Three teams have been shortlisted and the winning team will be announced in the summer (2011). The three teams are Dundee Kilmer Developments Limited, Legacy Village Partners and Village Infrastructure Partners (VIP).

- Waterfront Toronto, Toronto 2015 and the Ontario Realty Corporation should work with the City to ensure that ongoing funding from the federal and provincial governments is made available; this will limit the political and social backlash should the affordable housing targets not be actualized. Alternative funding strategies should also be explored, such as lend-lease arrangements. Funding will be needed both to convert the athlete housing into affordable units and to subsidize those units once they are occupied.

- The decisions and recommendations of the Waterfront Toronto's Design Review Panel should be upheld, despite the time pressure to get the Village completed for 2015. This will lower the likelihood of having of luxurious and large scale buildings that do not fit in with the intended context of the site. It will also allow for better protection of the built and natural heritage of the WDL. Further, it can allow for higher quality designs that will be perceived positively into the future. To do this, the City, Waterfront Toronto and the Design Review Panel should work together. 


\subsection{Consideration:}

- It is important to consider that the temporary use of the site as an Athletes' Village will speed up the development process for the West Don Lands community. As such, the original phased development outlined in the Precinct Plan is no longer feasible. The development was intended to be phased so that it would proceed logically and that the necessary public realm improvements, community amenities and required infrastructure would be provided to serve the site (WTRC, 2004). Initial development was to begin in District 1 and 3 and the Don River Park. District 3 was chosen to be developed first because it "provides an integration with the existing neighborhoods to the north and west and the Don River Park and incorporates the extension of River Street to the South" (WTRC, 2004). However, now district 2 will be developed first. As a result, careful consideration will need to occur so the site can be integrated with the rest of the

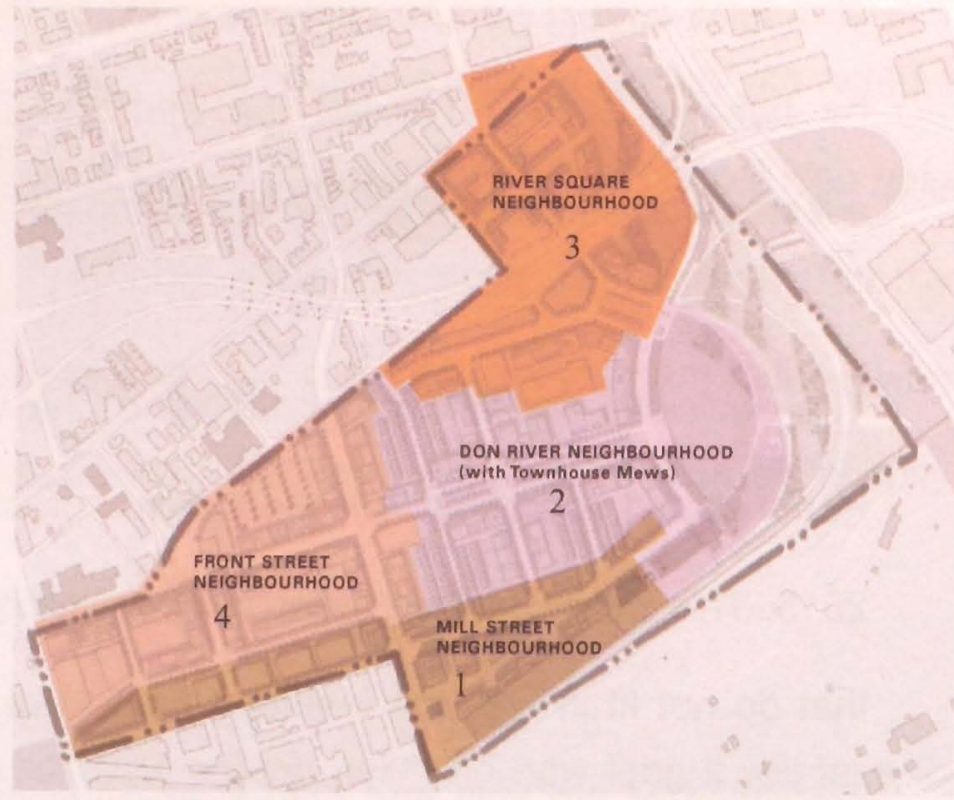

Figure 22: Four Neighborhood Districts Source: (WTRC, 2004)

City without focusing on District 3 . This should be done in partnership with Waterfront Toronto, Toronto 2015 and Infrastructure Ontario. 


\section{Appendix 1: Legacies of Mega-Events}

\begin{tabular}{|c|c|}
\hline Positive Legacies & Description \\
\hline Economic Stimulus & $\begin{array}{l}\text { - Job Creation: especially in construction and hospitality sectors (Gold \& Gold, } \\
\text { 2008; McCartney, 2010; Bret, 1984) } \\
\text { - Eg: } 2002 \text { Salt Lake City Olympic Games- generated an estimated } \\
35,000 \text { jobs per year between } 1996 \text { and } 2002 \text { (International Olympic } \\
\text { Committee, 2010) } \\
\text { - Inward Economic Investment: from national and international investors } \\
\text { Eg. } 1996 \text { Atlanta Olympic Games- in the decade following the Games } \\
280 \text { additional international businesses opened their offices there } \\
\text { (International Olympic Committee, 2010) } \\
\text { - Tourism Attraction: attracting visitors who want to watch the sporting events } \\
\text { (Potsiou, } 2005 \text {; Andranovich et al., 2001; Gold \& Gold, 2008) } \\
\text { - promotes the host city in a positive light; Games act as marketing and } \\
\text { publicity tool } \\
\text { - Generation of a Profit: often difficult to achieve } \\
\text { - Eg. } 1984 \text { LA Olympic Games- was able to generate a profit of over } \$ 2 \\
\text { million by using existing facilities and infrastructure rather than } \\
\text { building new ones, and by encouraging some private investment } \\
\text { (Andranovich et al., 2001) } \\
\text { - Eg. } 1996 \text { Atlanta Olympic Games- avoided deficit by encouraging } \\
\text { investors to buy advertising rights to the Games, leading to more } \\
\text { ticket sales (Kapadia, 2008) }\end{array}$ \\
\hline $\begin{array}{l}\text { Civic \& } \\
\text { Environmental } \\
\text { Betterment }\end{array}$ & $\begin{array}{l}\text { - City Beautification: park and street clean ups, tree plantings, improved } \\
\text { street lighting and better identification of national and local monuments } \\
\text { - Facilitates Social Interaction: brings people together to watch the games; } \\
\text { leaves behind sport venues and recreational centres (Bret, 1984) } \\
\text { - Recreational Enjoyment \& Athletic Excellence (Bret, 1984) } \\
\text { - Environmental Protection \& Enhancement: mainly through city clean-up } \\
\text { and expansion of parks and open spaces (Potsiou, 2005; Chalkey \& Essex, } \\
\text { 1999) } \\
\text { - Eg. } 1996 \text { Atlanta Olympic Games- Centennial Park was created by } \\
\text { greening } 10 \text { blocks of a blighted neighborhood; nearly } 2000 \text { trees } \\
\text { planted; several urban parks rejuvenated (International Olympic } \\
\text { Committee, 2010) }\end{array}$ \\
\hline $\begin{array}{l}\text { Urban Regeneration, } \\
\text { Renewal and } \\
\text { Improvement }\end{array}$ & $\begin{array}{l}\text { - Targets Specific Urban Problems: builds new facilities, expanding existing } \\
\text { infrastructure, and redeveloping blighted areas (Coaffe, 2008). } \\
\text { - Makes Projects More Feasible: financially \& politically justified spending; } \\
\text { speeds up timeline for completion; pushes projects to get started } \\
\text { - Eg. } 1992 \text { Barcelona Olympic Games- set precedent for using mega- } \\
\text { events to stimulate urban growth, beautification, waterfront; began } \\
\text { what is known as the Barcelona Model (Chalkey \& Essex, 1999) } \\
\text { - The City spent } \$ 517 \text { million on the construction of new facilities, including } \\
\text { a \$209 million sports stadium, } \$ 127 \text { million on an athletes' village, and } \\
\$ 50 \text { million on general infrastructural improvements (Andranovich et al., } \\
\text { 2001). }\end{array}$ \\
\hline
\end{tabular}




\begin{tabular}{|c|c|}
\hline Negative Legacies & Description \\
\hline Economic Impact & $\begin{array}{l}\text { - Financial Drain: diverts funding towards necessary infrastructure for Games } \\
\text { thereby impacting provision of education, health and social services } \\
\text { - Eg. } 1976 \text { Montreal Olympics- population was too small to support the } \\
\text { sudden and massive spending required for the Games (Millet, 2007) } \\
\text { Cost Overruns: difficult to plan proper budget as unforeseen expenses may } \\
\text { arise like inflated construction costs (Gratton et al., 2005; Gunderson-Hunt, } \\
\text { 2009) } \\
\text { - Long Term Maintenance Costs: especially with highly specialized facilities } \\
\text { required for an event like a velodrome (Chalkey \& Essex, 1999; Gold \& Gold, } \\
\text { 2008); facilities often very large and without high volume of users maintenance } \\
\text { costs are prohibitive (Swaddle, 2010) } \\
\text { - Eg. } 1976 \text { Montreal Olympics- the Olympic Stadium was demolished } \\
\text { in } 2000 \text { due to inability to secure a permanent tenant who could } \\
\text { afford the maintenance bill (Swaddle, 2010) }\end{array}$ \\
\hline $\begin{array}{l}\text { Civic Opposition, } \\
\text { Boycotts, Terrorism }\end{array}$ & $\begin{array}{l}\text { - Opposition to "Unjustified" Spending: question spending on facilities and } \\
\text { infrastructure necessary to host such events (Chalkey \& Essex 1998). } \\
\text { - Eg. } 1968 \text { Mexico City Olympic Games-activists protected against } \\
\text { spending money on Games in the face of extreme housing and } \\
\text { poverty issues in the City; culminated in } 250 \text { student deaths } \\
\text { (Chalkey \& Essex, 1999) } \\
\text { - Eg. } 2002 \text { Salt Lake City Olympics- protesters expressed concern } \\
\text { about provision of affordable housing and issues of civil liberties for } \\
\text { the homeless; more peaceful than Mexico City (Lenskyj, 2008) } \\
\text { - Overshadowing of Local Needs: tourist needs often believed to trump local } \\
\text { needs (Andranovich et al., 2001) } \\
\text { Exacerbate Local Inequalities: marginalized populations can be further } \\
\text { affected including elderly, minority groups, low income earners, homeless } \\
\text { (Chalkey \& Essex, 1999) } \\
\text { - Eg. } 1996 \text { Atlanta Olympic Games- construction of Centennial Park } \\
\text { created ill will among local residents who bore brunt of housing loss } \\
\text { and dislocation (Andranovich et al., 2001) } \\
\\
\text { "According to Andranovich et al., 2001, "providing festivals when people need } \\
\text { bread is a dubious use of public resources." }\end{array}$ \\
\hline
\end{tabular}




\section{Appendix 2: Case Study Profiles}

\subsection{The Sydney Olympic Village}

In 2000, Sydney, Australia hosted the summer Olympic Games, which were declared the "best ever" by the International Olympic Committee (IOC) president, Juan Antonio Samaranch (Sydney Olympic Park Authority, 2010). The Games, which went off without any major problems, brought numerous legacies to the City, many of which are intangible. Sydney was able to rebrand itself as a sophisticated, inclusive, tolerant and friendly society and gain international exposure (Garcia, 2009; Kapadia, 2008). According to Helen Wilson, a professor is New South Wales, Australia, the Games were "as much about the 'city spectacle' as they are about sports" (Garcia, 2009). Beyond the intangible, Sydney was able to achieve economic benefits through attracting international investment. However, of all the legacies, the most significant was the remediation of Homebush Bay, the site of the athletes' village and many of the major Games venues (Cashman, 2008).

The Village, which lies just $14 \mathrm{~km}$ to the west of the City-centre is 760 hectares in size (Chalkey \& Essex, 1998) and has undergone many layers of change, culminating in its current use (New South Wales, "Master Plan 2030", 2010). The site is situated on the traditional lands of the Wann-gal clan, but in the late eighteenth century the area was privately acquired. Salt pans, a tweed mill, limekiln and flour mills were established there, and later a horse racing tack and the Australian Jockey Club came in (New South Wales, "Master Plan 2030", 2010). In 1882 the north-eastern corner of the site was resumed by the State Government for the development of the Newington armaments depot, requiring major modifications to the natural environment (New South Wales, "Master Plan 2030", 2010). At the beginning of the twentieth century other industrial uses began to locate in the area, including the State Abattoir and Brickworks, and a gas production plant for AGL, further scaring the land with noxious uses (Chalkey \& Essex, 1998; New South Wales, "Master Plan 2030", 2010). The degradation of the site continued as the vast parkland began to be used as a landfill for urban waste, greatly contaminating the soil (New South Wales, "Master Plan 2030", 2010). In the early 1970s, regeneration plans for Homebush Bay were proposed and the renewal of the site began in the 1980s, beginning with the development of the Australia Centre Technology Park, Bicentennial Park and the State Sports Centre (New South Wales, "Master Plan 2030", 2010). However, winning the right to host the 2000 Olympic and Paralympic Games was the most notable transformative use of the site.

Hosting the Games acted as an impetus for Homebush Bay's redevelopment, quickly transforming it from a liability to an asset, and becoming the largest remediation of its kind in the history of Australia (Lochead, 2009; New South Wales, "Master Plan 2030", 2010). Over 9 million cubic meters of waste was remediated, transforming parts of it from a dumpsite to parklands (New South Wales, "Master Plan 2030", 2010), and approximately $\$ 137$ million was spent in cleanup efforts (Lochead, 2009; Lenskyj, 2002). Once the site was cleaned, the design and construction of the Village and its requisite infrastructure began. This involved employing a consortium of architects 
rather than an individual designer, in order to create a unique aesthetic appearance at Homebush Bay (Pitts, 2009). However, to ensure consistency and high quality design in the Village, development guidelines were put in place (Sydney Olympic Park Authority, 2010).

The Sydney Olympic Park differs from most other villages in that the athlete housing was located outside but adjacent to the main Park, in the Newington Suburb. Newington was designed to accommodate approximately 1,500 athletes in 520, two-storey courtyard villas, 350 low rise apartment units and 350 specially made modular dwellings (Pitts, 2009). Those modular homes were later relocated to mining camps and aboriginal reserves following the Games, and the athlete dorms converted into family dwellings (Pitts, 2009). In the adjacent main park, world class event venues were constructed, including the Olympic Stadium, a multi-use arena and a tennis, aquatic and athletic centre (New South Wales, "Master Plan 2030", 2010).

Following the Games, both Newington and Homebush Bay were to set a precedent for subsequent suburban developments in Sydney, especially in terms of environmental sustainability. The Bid made a formal pledge to have all buildings adhere to high environmental standards (Blunden, 2007; Sydney Olympic Park Authority, 2010). The mantra of the Village became the insurance of sustainable waste management, energy conservation, planning and construction. The heritage, biodiversity, water, air and soil on and around the village was to be protected (Sydney Olymipic Park Authority, 2010), and over 160 hectares of degraded land was restored (International Olympic Committee, 2010). Further, this resulted in the creation of one of the world's largest solar powered suburbs (in Newington), which generates the same amount of energy as that being used by the homes (Lochead, 2006) and one of the world's largest wastewater recycling systems (Mater Plan 2030, 2010). Since 2000, the Village has received over 70 national and international awards for its use of sustainable building materials, its water conservation and management system, waste management mechanisms, and its use of renewable energy (Lochead, 2006; Munoz, 1997). Further, Homebush Bay is recognized as being the site of Australia's largest metropolitan parkland, at 430 hectares, integrating within its confines ecologically significant wetlands, woodlands and flora and fauna and containing over $40 \mathrm{~km}$ of pedestrian trails and paths (Lochead, 2006; Sydney Olympic Park Authority, 2010; New South Wales, "Master Plan 2030", 2010).

As mentioned earlier, part of the bid focused on the creation of a prototype for future medium-density suburban developments across the country (Blunden, 2007). Despite this goal however, it became apparent after the Games that a lot of planning still needed to be done in order for that to happen. Numerous planning documents were created to govern the growth and conversion of the site, culminating in the Sydney Olympic Park Master Plan 2030, a 22 year vision for the site (New South Wales, "Master Plan 2030", 2010). This planning process slowed the conversion of the site from an athletes' village to a mixed-use community, however, progress has been made in recent years. 
Today, more than 60 businesses and 6,000 workers are located at Sydney Olympic Park and both numbers are expanding (New South Wales, "Master Plan 2030", 2010). Albeit the lack of forethought, the Sydney Olympic Village is frequently referred to as a prime example of how a degraded urban site can be returned to a sustainable and productive natural and cultural landscape and serves as a best practice example of sustainable urban development (New South Wales, "Master Plan 2030", 2010). It also demonstrates a strong housing legacy in the Newington suburb, which currently has over 5000 residents in 2000 houses (Newington Neighborhood Association, 2011).

\subsection{The Barcelona Olympic Village}

The Olympic model implemented by Barcelona for the 1992 summer Games has become synonymous with positive post- event legacies, specifically when it comes to urban planning and regeneration (Coaffee, 2008; Chalkey \& Essex, 1999). Barcelona has a history of using mega-events as a catalyst for urban transformations, beginning in 1888 with the Universal Exhibition (Monclus, 2008; Chalkey \& Essex, 1999). The reasons behind their earlier drive to host such events included the chance to enhance the Catalonian identity and bring prestige to the City and region (Chalkey \& Essex, 1999; Kapadia, 2009). Barcelona also hosts mega-events as an impetus for urban renewal; the $1992 \mathrm{Gmes}$ are cited as one of the best example of using a mega-event as a catalyst for urban betterment and revival (Chalkey \& Essex, 1998).

Part of their aim was to increase road networks by $15 \%$, the sewage system by $17 \%$, and increase the size of green zones and beaches by $78 \%$ (Cahyadi \& TenBrink, 2004). To achieve this, some projects included the construction of ring roads and integrated transportation routes, the clean-up and creation of parks and open spaces, the construction of needed sport and office facilities, and finally, opening up the City's waterfront to the sea (O'Connor, 2008; Monclus, 2008; Millet, 2005). One of the largest and most influential project was the construction of the athletes' village at Parc de Mar, a former industrial wasteland located in the Poblenou waterfront district and in close proximity to downtown Barcelona (O'Connor, 2008; Valera, 2002). They chose this site,despite the difficult clean up requirements, because of the positive regeneration legacy it would leave behind.

To allow for the development of the 130 hectare Parc de Mar (Chalkey \& Essex, 1999), remnants of Spain's industrial revolution, including old factories, warehouses and homes were demolished, along with the railway tracks that separated the site from the City (Holt, 1991; Valera, 2002; Monclus, 2008). This allowed the City to be opened up to the sea and acted as a catalyst for the cleaning up of some of the most degraded beaches in Spain (Monclus, 2008). According to the Mayor of Barcelona at the time of the games, Pasqual Margall, "Barcelona's hard working taxpayers are proud of the City's regeneration. They realize that this isn't just an investment for the Olympic Games, it is an investment in the future" (Holt, 1991).

The Village was designed to house approximately 3500 athletes in 2048 units in two residential towers (Carbonell, 2005; O'Connor, 2008). Like at Homebush Bay in Sydney, 
numerous architects were commissioned to design and supervise the construction of the Village (Carbonell, 2005; O'Connor, 2008), thereby resulting in a unique yet comprehensive design. Following the Games, the intention was to convert the Village into a mixed-use neighborhood with commercial, residential, service and leisure spaces (Carbonell, 2005). Unfortunately, however, as in Sydney, there was no intention to have any affordable or social housing units (Kapadia, 2005). Despite the inflated selling price of the units following the Games, the area became completely repopulated immediately after the games, a rarity for new developments near city centers (Valera, 2002).

The Village is now known as a "beacon for private investment" (O'Connor, 2008) and as a neighborhood with a high quality of life. It contains restaurants, bars, a casino and cinema, and retail stores (Carbonell, 2005). The former Olympic Gym has been converted into a multi- sport center with an indoor pool and sport facilities, and is open to the public. The two large residential towers were converted into an office building that employs over 3000 people and a luxury hotel (Carbonell, 2005). The area attracts more than 3 million visitors annually, many of which are tourists looking to enjoy the 18 hectares of remediated beaches (Kapadia, 2008), the vibrant night life, unique art, and the parks and open spaces there (Carbonell, 2005). Despite the mix of uses, the demographic make-up of the site is not diverse; the approximate 6000 residence of the neighborhood are generally young, well educated and affluent (Carbonell, 2005), which is not surprising given that the seafront condos are selling for five times more than their original asking price and most of the commercial and retail businesses are high end (Carbonell, 2005).

The urban transformation and regeneration legacies resulting from the Barcelona Games are often referred to as the Barcelona Model. Host cities worldwide aim to emulate the strong, long term strategic visioning, excellence in urban design and funding mechanisms of those Games (Coaffee, 2008). It acts as precedent for improving urban areas, as well as inspires sporting, economic, social and urban planners involved in organizing mega-events (Burnet, 2008).

\subsection{The Vancouver Olympic Village}

Vancouver won the right to host the 2010 winter Olympic Games on July 2, 2003. In comparison to summer Games, winter Games accommodate fewer athletes and attract fewer visitors (Rochon, 2010; Paperny-Mehler, 2010). By hosting, despite the smaller size of the Games, Vancouver was hoping to elicit a positive legacy of urban change, revitalization and regeneration for the City. According to the mayor at the time, Sam Sullivan, "We have a tremendous opportunity to use the 2010 Olympic and Paralympic Winter Games as a catalyst to solve the public disorder problems that affect our City" (Barr, 2009). As part of their method of generating positive urban change, the Athletes' Village was strategically built on the last undeveloped strip of the City's waterfront (Barr, 2009), also known as Southeast False Creek (City of Vancouver, 2010). The Southeast False Creek Village had been studied for its development potential for several years before the City won the Olympic bid, which is similar to the case of the WDL site. In 1999 the SEFC Policy Statement was drafted to guide the 
neighborhood development, and in 2003 an Official Development Plan was drafted for the site (The Challenge Series, 2010).

The development plan for the Athletes' Village, which occupied eight city blocks, was based on the Official Development Plan for Southeast False Creek, which was approved after numerous adjustments, by Vancouver's City Council in March 2005. The Official Development Plan (ODP) established a basis for the design and sustainability principles of the site. It envisioned developing the SEFC site into a community where people can live, work, and learn, and where social equity, livability, ecological health and economic prosperity is present. The concepts put forth in the ODP moved beyond the typical development model generally employed in Vancouver, and instead embraced a more European design style, thus it included an extensive public realm, low scale buildings, green design, shared amenities and authentic place-making at a human scale (The Challenge Series, 2010; Gunderson-Hunt, 2009). The Plan also focused on achieving a healthy and balanced social, environmental and economically sustainable neighborhood (The Challenge Series, 2010).

With the Plan in place, and with high public approval rates, the City was able to select a developer who could handle the task of building a 17-acre neighborhood in less than four years. The requirements to win the bid were tedious, and demanded developers to demonstrate that all buildings on the site would achieve LEED Silver certification, that the neighborhood was walkable, diverse and culturally rich, and that the former industrial use of the site was recognized (The Challenge Series, 2010). Further, all applicants needed to show that they could create a development that would support a diversity of housing types, including 1/3 market housing, 1/3 "modest" market housing and $1 / 3$ affordable housing, and respect the ODP (The Challenge Series, 2010). The housing requirements were later changed to $80 \%$ market housing and $20 \%$ affordable housing(The Challenge Series, 2010).

Out of five applicants, Millennium SEFC Properties was given the job due to their thoughtful consideration of the interim use of the site as an athletes' village, and their ability to offer "the best value to the City" (The Challenge Series, 2010). Their mandate was to develop and market the residential and commercial areas and to design and build both the community center and affordable housing for the City (The Challenge Series, 2010). Millennium utilized an Integrative Design Process (IDP) to set the development and design on the right path (The Challenge Series, 2010) and the Vancouver Organizing Committee (VANOC) provided some guidance by ensuring that the IOC and IDP requirements could be accommodated on the SEFC site. Further, the Urban Design Panel was appointed to ensure that a cohesive village identity was created (The Challenge Series, 2010), as was the case in Barcelona and Sydney. Together they came up with a series of 10 design principles that would guide the appearance of the site, including vertical streets, responsive building faces, integral amenity spaces, and a view from every floor (The Challenge Series, 2010). Through all of this collaboration, 1.5 million square feet of development, including 1100 units of housing, was created for the Games (The Challenge Series, 2010). 
Due to the tedious planning and design efforts, only relatively minor retrofits will be required for the conversion from an athletes' village to a neighborhood, many of which are still underway. The ground-level training, dining and health care spaces used during the Olympics are slowly being converted into restaurants and shops, and the athlete and official living quarters are being changed into permanent private dwellings (Barr, 2009; The Challenge Series, 2010). The neighborhood will eventually contain a mid rise grocery store, three daycares, a 45,000 square foot elementary school, an interfaith spiritual centre, five restored heritage buildings, 10 hectares of park/open spaces and community centre (City of Vancouver, 2010). The community centre will strive to achieve LEED Platinum certification.

The Village and its subsequent use is intended to act as a model of sustainable development, based on social, economic and environmental principles for the City (City of Vancouver, 2010) and thus the future residential units will be designed to meet USGBC Gold level standards, and all the buildings on the site will be high performance (Barr, 2009; City of Vancouver, 2010). It is estimated that approximately 12,000 to 16,000 people will be living in the Southeast False Creek Community by 2020 . They will be accommodated in over 5000 residential units with a variety of tenure types (City of Vancouver, 2010). Of the 5000 residential units, $20 \%$ were originally intended to be set aside for affordable and social housing, however that number has fallen (Hall, 2010).

The fate of the Southeast False Creek neighborhood is a highly contentious issue. Many of the units are not being sold, and the poor development budget of the site has resulted cost overruns that are being passed to taxpayers. The lack of sales can be attributed to the introduction of HST to the Vancouver, the high turnover of housing that exceeded the City's absorption ability, poor marketing strategies and the current economic condition recession (Hall, 2010). Although it is difficult to predict what will become of the Village so soon after the Games, it will be interesting to see how the City addresses some of the issues that have arisen. Further, as with all mega-events, host cities tend to look at prior games for lessons learnt, therefore what happens in Vancouver will be very important for Toronto to learn from. 


\section{References}

Andranovich, G., Burbank, M., \& Heying, C.H. (2001). Olympic cities: lessons learned from mega-event politics. Journal of Urban Affairs, 23 (2), pp. 113-131, Retrieved from http://journals1.scholarsportal.info.ezproxy.lib.ryerson.ca/details.xqy?uri=l 07352166/v23i0002/113_ocllfmp.xml

Baker, Linda (2011, February 22). In Vancouver, a new effort to sell condos. The New York Times [Online]. Retrieved on February 23, 2011 from http://www.nytime s.com/2011/02/23/realestate/commercial/23olympic.html?_r=1\&src=twrhp

Barcelona Field Studies Centre (2009, September 27). Barcelona: districts without life. Retrieved from http://geographylieldwork.com/OlympicVillage.htm

Barcelona Point (2009). Holidays at Barcelona's port olympic. Retrieved on April 1, 2011 from http://www.perfecttravelblog.com/practical_information_about_barcelo nal

Barr, Brian J. (2009, May 5). Vancouver's Olympic Village aims high on sustainability scale. Architectural Record. Retrieved from http://198.45.25.55/news/daily/archiv es/090505vancouver_sustainability.asp\#

Blunden, Hazel. Centre on Housing Rights and Evictions, (2007). The Impacts of the Sydney olympic games on housing rights, Geneva, Switzerland: COHRE. Retrieved from http://www.ruig-gian.org/ressourcesSydney_background_paper .pdf

Bret J.R, Ritchie (1984). Assessing the impact of hallmark events: conceptual and research issues. Journal of Travel Research, 23(2). Retrieved from http:// journals2.scholarsportal.info/details.xqy?uri=/00472875/v23i0001/2_atiohecar i.xml

Brooke, James (2004, August 18). After 4 years, Sydney's Olympic site starts to pay off. The New York Times [Online]. Retrieved on November 10, 2010 from http://www.nytimes.com/2004/08/18/business/after-4-years-sydney-s-olympicsite-starts-to-pay-off.html

Cahayadi, G., \& TenBrink, S. (2004, July). Barcelona metropolitan economic strategy. Retrieved from http://www.globalurban.org/GUD\%20Barcelona\%20MES \%20Report.pdf

Campion, Vikki (2010, September 1). Game to call Athletes' Village home. The DailyTelegraph [Online]. Retrieved on December 10, 2010 from http:/l www.dailytelegrap h.com.au/news/nsw-act/game-to-call-athletes-village-home/ storye6freuzi-1225912529895 
Carbonell, Jordi. (2005). The Olympic Village, ten years on: Barcelona: the legacy of the Games, 1992-2002. Barcelona: Centre d'Estudis Olimpics UAB. Retrieved on November 28, 2010 from http://olympicstudies.uab.es/pdf/wp087_eng.pdf

Cashman, R.(2008). Regenerating Sydney West: Framing and Adapting an Olympic Vision. In G. Poynter \& I. MacRury (Ed.), Olympic Cities: 2012 and the Remaking of London. (pp.133 -144). Great Britain and New York: Ashgate Publishing Limited.

Chalkey, B., Essex, S. (1999). Urban development through hosting international events: a history of the Olympic Games. Planning Perspectives, 14 (4), pp. 369-394. Retrieved from http://web.ebscohost.com.ezproxy.lib.ryerson.ca/ehost/ pdfviewer/pdfviewer?hid=10\&sid=\{9371ac1-de7c-49e3-afb3-2fcf59c4131a\%40s essionmgr11\&vid $=4$

Chalkley, B., Essex, S. (1998). Olympic Games: Catalyst of Urban Change. Journal of Leisure Studies, 17 (3) pp. 187-206. Retrieved from http://www.informaworl d.com/smpp/ftinterface $\sim$ content $=a 713777036 \sim$ fulltext $=713240930 \sim \mathrm{frm}=$ content

City of Vancouver (2010, July 29). Southeast False Creak and Olympic Village. Retrieved on February 2, 2011 from http://vancouver.ca/olympicvillage/officialdev plan.htm

City of Vancouver (2007). Southeast False Creek Official Development Plan, Official Development Plan By-Laws. Retrieved from http://vancouver.ca/commsvcs/ bylaws/odp/SEFC.pdf

Coaffee, J.(2008). Urban Regeneration and Renewal. In J.R. Gold M.M. Gold (Ed.), Olympic Cities: City Agendas, Planning, and the World's Games, 1896-2016 (pp. 180-194). London New York: Routledge.

Coupland, Andy. (1997). Reclaiming the city: mixed-use development. London: E\&FN Spon.

Garcia, B.(2008). Sydney 2000. In J.R. Gold \& M.M. Gold (Ed.), Olympic Cities: City Agendas, Planning, and the World's Games, 1896-2016 (pp.286-313). London \& New York: Routledge.

Gold, J.R., Gold, M.M. (2008). Olympic cities: regeneration, city rebranding and changing urban agendas. Geography Compass, 2 (1), pp. 300-318. Retrieved from http://onlinelibrary.wiley.com.ezproxy.lib.ryerson.ca/doi/10.1111/j.1749-81 98.2007.00080.x/abstract 
Gratton, C., Shibli, S., Coleman, R. (2005). Sport and economic regeneration in cities. Urban Studies, 42 (5/6), pp. 985-999. Retrieved from_http://journals1.scholar sportal.info.ezproxy.lib.ryerson.ca/details.xqy?uri=/00420980/v42i5-6/985_sa eric.xml

Gunderson- Hunt, Kristin (2009). Golden opportunity: the Olympics offer long term benefits to real estate managers and their cities. Journal of Property Management, 74, (6), pp. 40-44. Retrieved from http://proquest.umi.co m.ezproxy.lib.ryerson.ca/pqdlinkindex $=1 \& d i d=1927266801 \&$ SrchMode $=3 \&$ sid $=1 \& \mathrm{Fmt}=6 \&$ VInst $=$ PROD \&VType $=P Q D \& R Q T=309 \& V$ Name $=P Q D \& T S=12982$ $56452 \&$ clientld $=10120$ \&aid $=1$

Hall, Neal (2010, September 30). Vancouver Olympic Village developer defaults on Ioan payment. Vancouver Sun [Online]. Retrieved on November 10, 2010 from http://www.vancouversun.com/business/Vancouver+Olympic+Village+developer +defaults+loan+payment/3605636/story.html

Hanes, Allison (2009, August 28). Opposition to Pan Am Games emerges on eve of official tour. The National Post [Toronto].

Hanes, Allison (2008, October 3). Race is on for Pan Am Games. The National Post [Toronto].

Hemphill, L., McGreal, S., \& Berry, J. (2004). An indicator-based approach to measuring sustainable urban regeneration performance: part 2, empirical evaluation and case-study analysis. Urban Studies 41(4) pp. 757-772. Retrieved from http://usj.sagepub.com/content/41/4/725.full.pdf

Holt, Hackney (1991). Olympic divided. Financial World, Vol. 160, No. 7, pp. 78-80.

Hume, Christopher. (2008, September 11). City's self -esteem at stake in Games bid. The Toronto Star [Toronto].

IBI Group. City of Vancouver, (2002). Southeast False Creek transportation study Vancouver: British Columbia: Retrieved from http://vancouver.ca/commsvcs/ southeast/documents/pdf/transportfinalreport.pdf

Infrastructure Ontario (2010). Alternative Financing and Procurement. Retrieved on February 2, 2011 from http://www.infrastructureontario.ca/en/projects/afp.asp

International Olympic Committee (January 2010). Factsheet: legacies of the Games. Retrieved on December 4, 2010 from http://www.olympic.orgDocumentsRefere nce_documents_Factsheets/Legacy.pdf

Inwood, D., Spencer, K. (2010, September 8). Taxpayers on hook for \$1B Olympic 
Village 'ghost town'. The Gazette [Online]. Retrieved on November 10, 2010 from http://www.montrealgazette.com/business/Taxpayers+hook+Olympic+Villag e+ghost+town/3496973/story.html

Jacobs, Steve (2001, October 17). Athlete's Homes a Fine Fit in Suburbia. South China Morning Post [Online]. Retrieved on December 4, 2010.

Kapadia, Sarita (Fall 2008). Olympics and housing: a look into the treatment of undeserved populations before and after the Games. Senior Thesis: Harveford College. Retrieved from http://triceratops.brynmawr.edu/dspace/bitstream/handle/ 10066/3725/2009KapadiaS(Abridged).pdf?sequence $=7$

Klassen, Mike (2010, October 3). Geller's 'reality check' on the Olympic Village. Retrieved on Jan 21, 2011 from http://www.citycaucus.com/2010/10/gellersreality-check-on-the-olympic-village

Lavoie, Joanna (2011, February 9). Athletes' Village design team shortlist. Retrieved on February 11, 2011 from http://www.insidetoronto.com/news/local/article/952069-Athlete-s-village-design-team-short-list

Lenskyj, Helen (2002). The best Olympics ever? social impacts of Sydney 2000. Albany: State University of New York Press.

Lenskyj, H.J. (2008). Olympic industry resistance: challenging Olympic power and propaganda. Albany: State University of New York Press.

Lewington, Jennifer (2009, February 27). West Don Lands top spot for Athletes' Village. The Globe and Mail [Toronto].

Lochead, Helen. (2006). A vision for Sydney Olympic Park. Proceedings of the ICTC Conference. Retrieved from http://www.ictcsociety.org/LinkClick.aspxfilet icket $=3 \mathrm{NIYWjO} \% 2 \mathrm{BzfQ} \% 3 \mathrm{D} \& \mathrm{tabid}=129 \& \mathrm{mid}=548$

Lu, Vanessa (2008, October 10). Pan Am success could pave way for Olympic Bid. The Toronto Star [Toronto].

Lu, Vanessa (2009, November 3). A vision beyond 2015. The Toronto Star [Toronto].

Lura Consulting, Toronto Waterfront Revitalization Corporation, (2004). West Don Lands Precinct Plan public consultation- summary report. Toronto, Ontario.

MacFarlane, David (2010 January). The age of spectacle. Toronto Life [Online]. Retrieved on November 10, 2010 from http://www.torontolife.com/features/agespectacle/ 
Mays, John B. (2009, November 19). The race to build a Pan Am Games Village has begun. The Globe and Mail [Online]. Retrieved on November 10, 2010 from http://www.theglobeandmail.com/real-estate/the-race-to-build-a-pan-am-gamesvillage-has-begunarticle1370223/

McCartney, Gerry (2010). The health and socioeconomic impacts of major multi-sport events: systematic review (1978-2008). British Medical Journal. Retrieved from http://www.bmj.com/content/340/bmj.c2369.abstract doi: 10.1136/bmj.c2369

Mehler-Paperny, Anna (2009, Nov 16). Pan Am Games puts Don Lands into high gear. The Globe and Mail [Toronto].

Millennium OV Properties Ltd., Merrick Architecture \& GBL Architects Group Inc.(2006). Rezoning Submission for the Development of Southeast False Creek Sub-Area $2 A$ Including the Olympic Village. Retrieved from http://vancouver.ca/commsvcs/ southeast/public/06augSubArea2ARezSub/cover.pdf

Millet, Lluís. (1995). The games of the city. Barcelona: Centre d'Estudis Olímpics UAB. Retrieved on November 28, 2010 from http://olympicstudies.uab.es/pdfwp046_e ng.pdf

Monclus, F.J.(2008). Barcelona 1992. In J.R. Gold \& M.M. Gold (Ed.), Olympic cities: city agendas, planning, and the world's games, 1896-2016 (pp.268-286). London \& New York: Routledge.

Munoz, Francesc. (1997). Historic Evolution and Urban Planning Typology of Olympic Villages. Barcelona: Centre d'Estudis Olimpics UAB. Retrieved on October 27, 2010 from http://olympicstudies.uab.es/pdf/wp091_eng.pdf

Neuman, Lawrence (2006). Social Research Methods: Qualitative and Quantitative Approaches, 6th edition. Pearson Education Inc.: United States.

Newington Neighborhood Association (2011). About Newington. Retrieved from http:// www.newingtoncommunity.com.au/

New South Wales Government. Sydney Olympic Park Authority. Sydney Olympic Park Master Plan 2030. Sydney: Crown Copyright, 2010.

O'Connor, Margaret (2008, August 2). Building for gold: the lessons of past Olympic Athletes' Villages are being applied in Beijing and London. The Financial Times, London, UK [Online]. Retrieved on December 10, 2010 from http://journalisted.c $\mathrm{om} / \mathrm{margaret-oconnor?allarticles=yes}$

Pitts, A., Hanwen, L. (2009). Sustainable olympic design and urban development. London, New York: Routledge. 
Potsiou, Chryssy, A. (April 2005). Greece after the gold rush: impact analysis and sustainability of the 2004 Olympic infrastructure. National Technical University of Athens: School of Rural and Surveying Engineering. Retrieved from http:// www.gsdidocs.org/gsdicont/GSDI-8/ppt/ts_09/ts09_01_potsiou_etal_ppt.pdf

REA Group (n.d). Houses in Newington. Retrieved on April 1, 2011 from http://www.realestate.com.au/sold/property-house-in-newington, +nsw+2127/list-2

Rivera, R. \& Wooten, R. (2002). Public involvement plan for the Kelly Parkway corridor study context sensitive design. Retrieved from http://www.urbanstreet.info/2nd_sym_ proceedings/Volume\%202/Rivera.pdf

Rochon, Lisa (2010, March 3). Toxic soil, troubling questions and a ticking clock. The Globe and Mail [Toronto].

Starr, Ryan (2010, February 27). On your mark, get set for Pan Am Games. The Toronto Star [Online]. Retrieved on November 10, 2010 from http://www.yo urhome.ca/homes/newsfeatures/article/771076--on-your-mark-get-set-for-panam-games

SuperStock (2011). Olympic Port: Olympic Village. Retrieved on April 1, 2011 from http://www.superstock.com/stock-photos-images/1566-358483

Swaddle, Paul (May 2010). Post Olympic legacy: learning from former host cities. NBS News [Online]. Retrieved on November 10, 2010 from http://www.thenbs .com/topics/designspecification/articles/postOlympicLegacy.asp

Sydney Olympic Park Authority (2010). Sydney Olympic Games history. Retrieved on November 13, 2010 from http://www.sydneyolympicpark.com.au/education_a nd_learning/history/olympic_history

Terefenko, Paul (November 2009). Pan Am Games pressure points: here's where we could stumble in the dash to 2015. Now News [Online]. Retrieved on October 28, 2010 from http://www.nowtoronto.com/news/story.cfm? content $=172479$

The Challenge Series [2010]. Millennium water: the Southeast False Creek OlympicVancouver, Canada. Retrieved on February 2, 2011 from http://www.thechallengeseries.ca/about/

The Co-operative Housing Federation of Canada (n.d). Selection Process for Toronto 2015 Pan/Parapan American Games Legacy Affordable Homes. Retrieved on March 31, 2011 from http://www.chfcanada.coop/eng/pdf/ontdocs/Affordable $\% 20$ Housing\%20Information\%20Notice.pdf 
Toronto 2015 (2008). Your Moment is Here: Pan American and Parapan American Games. Retrieved from http://www.toronto2015.org/lang/en/toronto-2015-games/ panparapan-am-village.html

Valera, S. \& Guardia, J. (2002). Urban social identity and sustainability: Barcelona's Olympic Village. Environment and Behavior, 34(1), pp. 54-66. Retrieved from http://journals1.scholarsportal.info.ezproxy.lib.ryerson.ca/tmp/98218836406332 6507.pdf

Waterfront Toronto (2010). West Don Lands. Retrieved from http://www.waterfrontor onto.ca/explore_projects2/west_don_lands

Waterfront Toronto \& Toronto Transit Corporation (2008). West Don LandsTransit Class Environmental Assessment. Retrieved from www.waterfrontoron to.ca/widgets_document/download-document/.../0

Waterfront Toronto Revitalization Corporation (2004). The West Don Lands Precinct Pan. Retrieved from http://www.waterfrontoronto.ca/explore_projects2/ west_don_lands/planning_the_community

Waterfront Toronto Revitalization Corporation (2005). West Don Lands backgrounder. Retrieved from http://www.waterfrontoronto.ca/dbdocs//485002b030e49.pdf

West Don Lands Committee (2000). Obstacles and Opportunities: Realizing the Potential of the West Don Lands, November 18-20, 1999, Workshop Final Report. Toronto: West Don Lands Committee. 